\title{
Current Internal-Dosimetry Practices at U.S. Department of Energy Facilities
}

\author{
R.J. Traub \\ B.L. Murphy \\ J.M. Selby \\ E.J. Vallario
}

April 1985

Prepared for the U.S. Department of Energy under Contract DE-AC06-76RLO 1830

Pacific Northwest Laboratory Operated for the U.S. Department of Energy by Battelle Memorial Institute 


\title{
DISCLAIMER
}

This report was prepared as an account of work sponsored by an agency of the United States Government. Neither the United States Government nor any agency thereof, nor any of their employees, makes any warranty, express or implied, or assumes any legal liability or responsibility for the accuracy, completeness, or usefulness of any information, apparatus, product, or process disclosed, or represents that its use would not infringe privately owned rights. Reference herein to any specific commercial product, process, or service by trade name, trademark, manufacturer, or otherwise, does not necessarily constitute or imply its endorsement, recommendation, or favoring by the United States Government or any agency thereof. The views and opinions of authors expressed herein do not necessarily state or reflect those of the United States Government or any agency thereof.

\author{
PACIFIC NORTHWEST LABORATORY \\ operated by \\ BATTELLE \\ for the \\ UNITED STATES DEPARTMENT OF ENERGY \\ under Contract DE-AC06-76RLO 1830
}

\begin{tabular}{|c|c|}
\hline \multirow{2}{*}{\multicolumn{2}{|c|}{ Printed in the United States of America }} \\
\hline & \\
\hline \multicolumn{2}{|c|}{$\begin{array}{c}\text { Available from } \\
\text { National Technical Informati }\end{array}$} \\
\hline \multirow{3}{*}{\multicolumn{2}{|c|}{$\begin{array}{c}\text { United States Depanment of Commerce } \\
5285 \text { Port Royal Road } \\
\text { Springfield, Virginia } 22161\end{array}$}} \\
\hline & \\
\hline & \\
\hline \multirow{2}{*}{\multicolumn{2}{|c|}{$\begin{array}{l}\text { NTIS Price Codes } \\
\text { Microfiche } A 01\end{array}$}} \\
\hline & \\
\hline \multicolumn{2}{|c|}{ Printed Copy } \\
\hline & Price \\
\hline Pages & Codes \\
\hline 001-025 & $\mathrm{A} 02$ \\
\hline $026-050$ & $\mathrm{~A} 03$ \\
\hline 051-075 & $\mathrm{AOA}$ \\
\hline $076-100$ & A05 \\
\hline $101-125$ & $A 06$ \\
\hline $126-150$ & A07 \\
\hline $151-175$ & $\mathrm{~A} 08$ \\
\hline $176-200$ & A09 \\
\hline $201-225$ & A010 \\
\hline $226-250$ & ^011 \\
\hline $251-275$ & A012 \\
\hline $276-300$ & A013 \\
\hline
\end{tabular}


R. J. Traub
B. L. Murphy
J. M. Selby
E. J. Vallario (a)

ApriT 1985

Prepared for the U.S. Department of Energy under Contract DE-ACO6-76RL0 1830

Pacific Northwest Laboratory

Richland, Washington 99352

(a) U.S. Department of Energy 
The Office of Nuclear Safety (ONS) of the Department of Energy (OOE) initiated a study during FY-83 to review the status of Internal Dosimetry Programs at DOE and DOE contractor facilities.

The purpose of this study was to determine the adequacy of present programs and identify areas for improvement. This report is based upon the responses provided by $\mathrm{DOE}$ contractors throughout the U.S. Knowledge of the site-specific internal dosimetry programs is a necessary prerequisite for the identification of feasible alternatives to the upgrading of internal dosimetry practices.

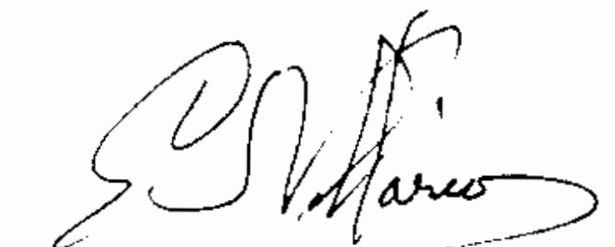

E. J. Vallario, Group teader Health Physics Programs Radiological Controls Division Office of Nuclear Safety U.S. Department of Energy 


\section{SUMMARY}

This report summarizes the findings of a study conducted for the Office of Nuclear Safety, Department of Energy (DOE) to assess the internal-dosimetry programs at $D O E$ facilities. The purposes of the study were ${ }^{(a)}$ to characterize the facilities' internal-dosimetry practices, assess the uniformity of those practices among the facilities, identify the concerns of health physicists at the facilities about internal dosimetry, and assess the ability of the internal-dosimetry programs at the facilities to meet changes that may make internal dosimetry a more difficult task than it already is.

The information gathered from the questionnaire responses illustrates the diversity of internal-dosimetry practices at DOE facilities. The differences among the internal-dosimetry programs are related to the radioelements in use at each facility and, to some extent, the number of workers at each facility. The differences include different frequencies in the use of quality control samples, different minimum detection levels, different methods of recording radionuclides, different amounts of data recorded in the permanent record, and apparent differences in modeling the metabolism of radionuclides within the body.

The responses to the questionnaire indicated that the individuals responsible for internal dosimetry at DOE facilities were concerned about the accuracy and reliability of the methods used to estimate uptakes of radioactive materia's and the radiation doses resulting from the uptakes. Specifically, the radiation detection methods did not have the spatial resolution needed to quantify radioactive materials in individual body organs, except for a few instances such as iodine in the thyroid, and the mathematical models that describe the distribution of radioactive material within the body were not sufficiently accurate to predict the organ depositions in specific individuals. Another concern was the method used to assign a date of intake when the actual date is unknown.

(a) This report was written in the present tense. It represents the state of Internal Dosimetry Programs in November 1983, the time when the questionnaires were answered. 
Recommendations for improving internal-dosimetry practices include studying the relationship between air-monitoring/survey readings and bioassay data, establishing uniform methods for recording bioassay results, developing more sensitive direct-bioassay procedures, establishing a mechanism for sharing information on internal-dosimetry procedures among DOE facilities, and developing mathematical models and interactive computer codes that can help quantify the uptake of radioactive materials and predict their distribution in the body. 


\section{ACKNOWLEDGMENTS}

The authors would Tike to thank the individuals at the DOE facilities and DOE field offices who took the time to respond to the questionnaire and whose responses form the basis for this report. The authors would also like to express their very great appreciation to Marianna Cross for the preparation of this report and to J. L. Baer, who edited the report. In addition, the comments and suggestions of the staff of the Radiological Sciences and the Occupational and Environmental Protection Departments are gratefully acknowledged. 


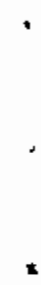

๘

1

,

เ 


\section{CONTENTS}

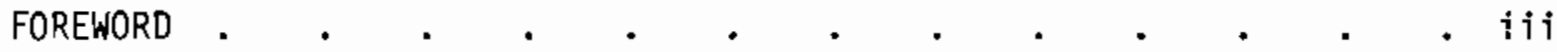

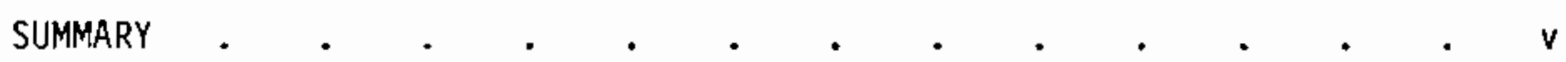

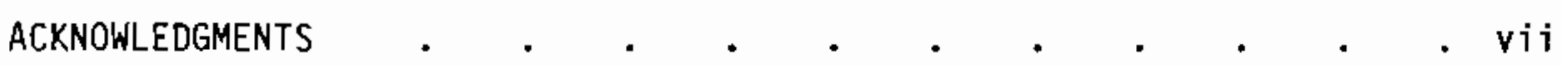

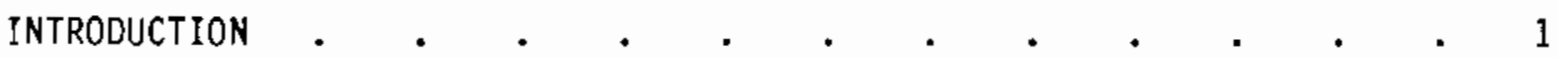

STUDY APPROACH . . . . . . . . . . . . 3

RESPONDENTS . . . . . . . . . . . . . . . . 4

GENERAL INFORMATION •

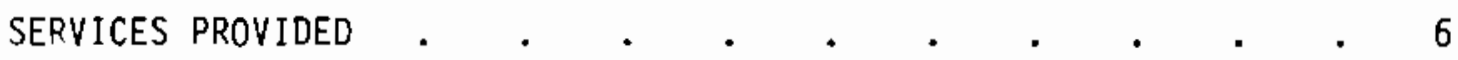

SIZE OF PROGRAMS . . . . . . . . . . . . . . . 6

PERCENTAGE OF MAXIMUM OOSE LIMIT RESULTING FROM INTAKES • • 6

DOCUMENTATION

BIOASSAY PROCEDURES . . . . . . . . . . . . . . . . . 10

BASIS FOR INTERNAL OOSE ESTIMATION • . $. \quad \cdot \quad . \quad \cdot \quad \cdot 10$

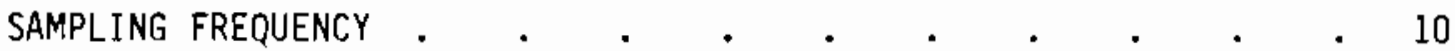

NUMBERS ANO TYPES OF ASSAYS PERFORMED $\quad . \quad \cdot \quad \cdot \quad . \quad \cdot \quad \cdot 11$

DATA ANALYSIS/INTERPRETATION

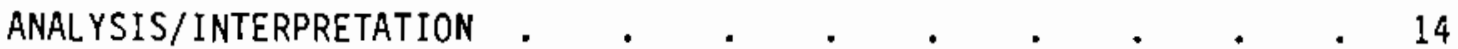

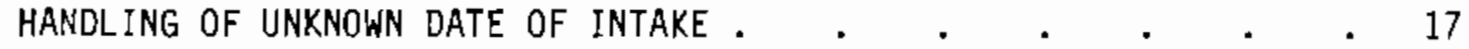

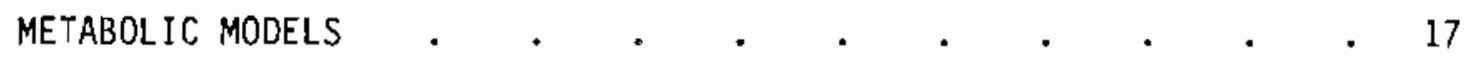

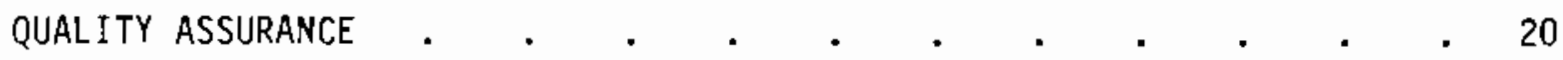

QUALITY ASSURANCE PROGRAMS $. \quad . \quad . \quad . \quad . \quad . \quad . \quad$. 20

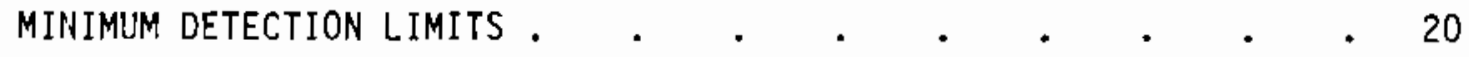

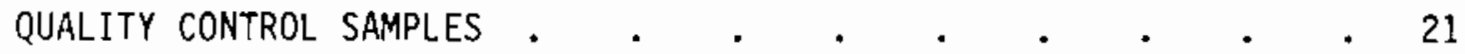

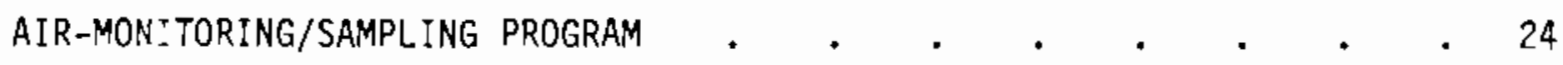

GENERAL INFORMATION • 


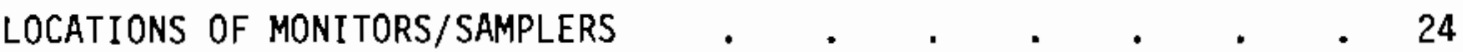

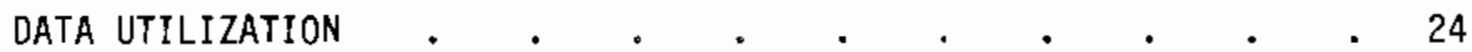

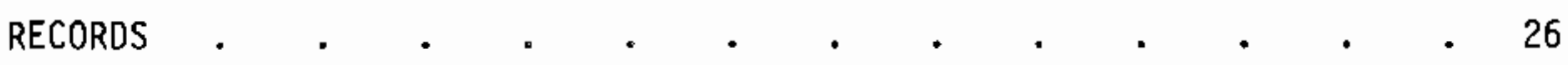

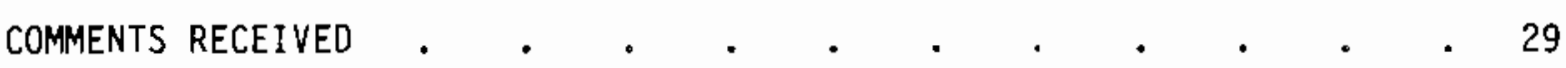

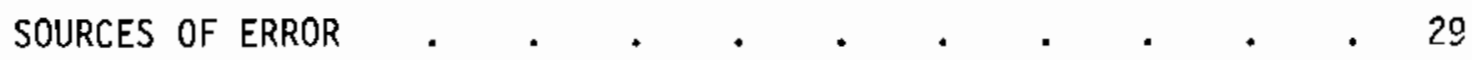

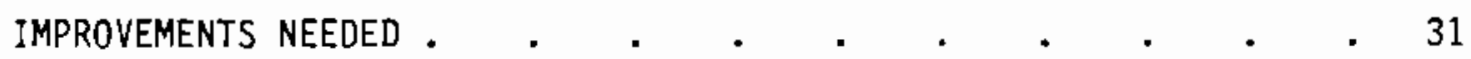

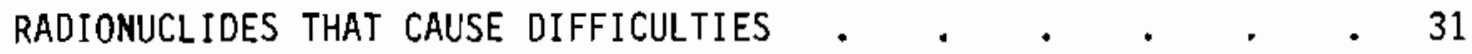

\begin{tabular}{l} 
ADEQUACY OF INTERNAL DOSIMETRY FOR EFFECTIVE DOSE \\
EQUIVALENT \\
\hline
\end{tabular}

PROGRAMMATIC REQUIREMENTS FOR EFFECTIVE DOSE EQUIVALENT

GENERAL • . . . . . . . . . . . . . 33

RECOMMENDATIONS FOR IMPROVING INTERNAL-DOSIMETRY PRACTICES . . . • 34

UNIFORM BIDASSAY PROCEDURES AND DATA RECORDING.$\quad \cdot \quad \cdot \quad$ • 34

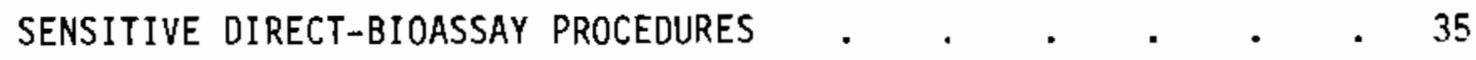

DOE INTERLABORATDPY INFORMATION INTERCHANGE $\quad \cdot \quad \cdot \quad \cdot \quad \cdot \quad \cdot \quad 35$

DEVELOPMENT' OF MODELS AND INTERACTIVE COMPUTER CODES . • . 36

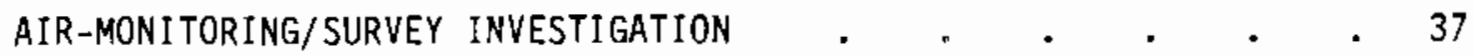

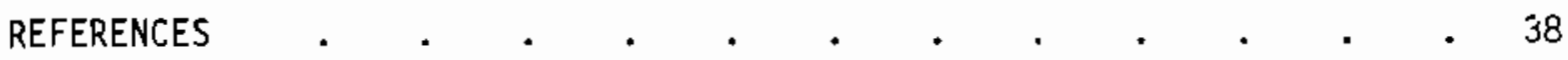

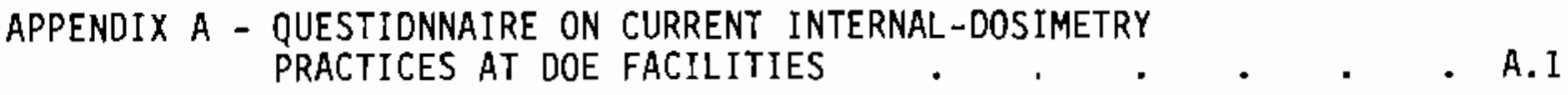

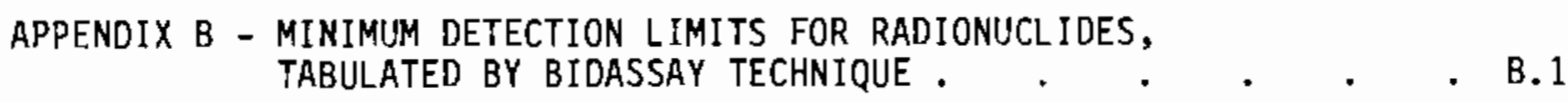




\section{$\underline{\text { TABLES }}$}

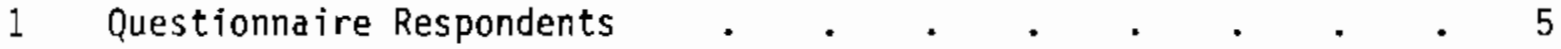

2 Number of Workers in Percentage Categories of Maximum Uptake $\quad 8$

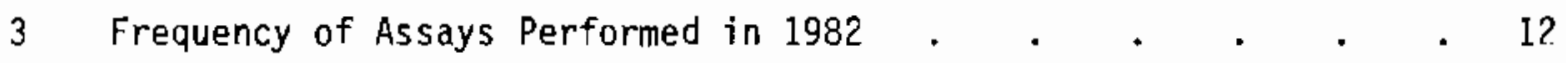

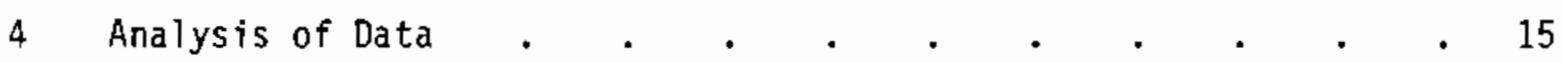

5 Assumptions Made Regarding Unknown Date of Intake . . . . 18

6 Frequency of Use of Quality Control Samples . . . . . . . 22

7 Auxiliary Locations of Air Samplers/Monitors . . . . . . . 25

8 Parameters Inciuded in Personnet Dosimetry Systems . . . 27 


\section{INTRODUCTION}

The quantification of radiation dose to an individual from radioactive material contained within the body is one of the most difficult tasks facing operational health physicists. The radiation dose is dependent upon the amount of radioactive material taken into the body, the distribution of the radioactive material within the body, and the rate at which the radioactive material is eliminated from the body; all of which are difficult to quantify with great accuracy.

The quantity of radioactive material in the body may be estimated by one of two general methods, direct bioassay and indirect bioassay. Direct bioassay consists of counting the radiations emanating from radioactive isotopes within the body by a radiation detector outside the body. The radioactive content of the body is estimated from the number of radiations detected and the counting efficiency of the radiation detector for that radiation. Indirect bioassay consists of analyzing the radioactive content of body fluids and excreta. The radioactive content of the body is estimated by use of mathematical models of radioisotope excretion that attempt to relate excretion rate on a given date to uptake of radioactive material on a previous date. After the radioactive content of the body is estimated, the radiation doses may be estimated.

Three recent changes or proposed changes--in measurement concepts, annual limits for internal dose, and procedures for preparing isotopically-pure samples of radioelements such as plutonium--may serve to make the task of evaluating internal doses more complex.

- Historically, the major emphasis for internal dosimetry has been placed upon quantifying the radiation dose to a critical organ, which was defined by the International Commission on Radiological Protection in ICRP Publication 2 (1959) as "that organ of the body whose damage by the radiation results in the greatest damage to the body." In its recommendations of 1977 and 1979 (Publications 26 and 30), ICRP introduced the concept of effective dose equivalent. The effective dose equivalent is the sum of the products of a 
weighting factor and the organ dose for eleven organs: the gonads, breast, red bone marrow, lung, thyroid, bone surfaces, and the five organs of the remainder receiving the highest dose equivalents. In order to compute the effective dose equivalent, it is necessary to quantify the radioactive content, and therby the radiation dose, of several body organs in addition to the critical organ.

- The ICRP has introduced in Publication 30 the concept of annual 1 imit on intake (ALI), which represents the amount of radioactive material that may be taken into the body without exceeding certain criteria recommended by ICRP. The ALIs for radioelements retained in the body for long half-times are so low that they may approach the limits of detection for current techniques and instruments.

- PTutonium-239, which is used by the Department of Energy (DOE) and its contractors in the operation of reactors and in research in support of defense programs, is difficult to quantify when it is inside the body: the only penetrating radiation resulting from decay is a low-energy $x$ ray that is emitted from the body with low frequency. To date, however, quantifying ${ }^{239} \mathrm{Pu}_{\mathrm{u}}$ in the body has generally been possible because currently available samples of ${ }^{239} \mathrm{Pu}$ contain a small amount of ${ }^{241} \mathrm{Am}$, a radioactive decay product of ${ }^{241} \mathrm{Pu}$ which is also present in most samples of ${ }^{239} \mathrm{Pu}$. Americium-241 contained in the body can be readily detected by instruments outside the body and has therefore been used as a "tag", or tracer, to help heal th physicists detect and quantify internal depositions of plutonium. Recently developed methods of separating isotopes using Tasers will in the future provide plutonium that is virtually free of ${ }^{241} \mathrm{Pu}$ and therefore also free of ${ }^{241} \mathrm{Am}$. Consequently, future methods for directly quantifying plutonium within the body will have to be able to detect the plutonium directly, without the assistance of tracers.

The ability of health physicists at DOE facilities (a) to adapt their internal-dosimetry programs to meet these and other changes was unknown, as

(a) DOE facilities refers to facilities, ejther government-owned or privately owned, that conduct DOE programs. 
was the extent of uniformity in the facilities' internal-dosimetry practices. Therefore, the U.S. Department of Energy (DOE) initiated a study to characterize the internal-dosimetry practices at DOE facilities. (a) The purpose of the study was to determine the size of the facilities' internal-dosimetry programs, the uniformity of the programs among the facilities, and the areas of greatest concern to health physicists in providing and reporting accurate estimates of internal radiation dose and in meeting proposed changes in internal dosimetry.

\section{STUDY APPROACH}

The study was conducted by means of a questionnaire. The topics covered inciuded:

- general information about the internal-dosimetry program

- documentation procedures

- bioassay procedures

- data analysis and interpretation

- quality assurance

- air-monitoring and sampling program

- records.

The majority of the questions were structured to require only a check mark to indicate whether a certain practice was followed or which of several alternatives applied. Where simple yes-or-no answers would be inappropriate, the respondents were asked to fill in tables or to provide short answers. They were also encouraged to annotate the questionnaire and to expand on any topic they wished. The final section of the questionnaire requested comments, and several topics for comment were suggested.

The questionnaire and the total numbers of responses to the check-answer questions are provided in Appendix A. The short answer responses are tabulated win the discussion sections of the report. The long answer responses are inc uded in tables of individual answers; when a respondent left that section blank, their number was omitted from the table. For the convenience of the reader, this report has the same structure as the questionnaire.

(a) This report was written in the present tense. It represents the state of internal dosimetry programs in November 1983, the time when the questionnaires were prepared. 


\section{RESPONDENTS}

Responses to the questionnaires were received from 29 facilities, which are listed alphabetically in Table 1. Each facility was assigned a number based on the order in which the responses were received. Therefore, there is no correlation between the alphabetical list in Table 1 and the numbering of the facilities in the data compilation used throughout this report.

From the responses, it became clear that at laboratory sites that have more than one contractor, all of the contractors responded to the questionnaire, but only one or a few of them actually perform bioassays. It also became clear that the breakdown of responsibilities varies from site to site. That is, a contractor who is responsible for analyzing bioassay samples may or may not be responsible for interpreting the analyses, and also may or may not be responsible for keeping the internal-dosimetry records. 


\section{TABLE 1. Questionnaire Respondents}

Argonne National Laboratory, Argonne, Illinois

Argonne National Laboratory-West, Idaho Falls, Idaho

Battelle-Pacific Northwest Laboratories, Richland, Washington

Brookhaven Nationa 7 Laboratory, Upton, New York

EG\&G, Idaho Co., Inc. (INEL), Idaho Falls, Idaho

Exxon Nuclear Idaho Co., Inc., Idaho Falls, Idaho

Feed Materials Production Center, Cincinnati, Ohio

Fermi National Accelerator Laboratory, Batavia, Illinois

Goodyear Atomic Corporation, Piketon, Ohio

Inhalation Toxicology Research Institute, Albuquerque, New Mexico

Lawrence Berkeley Laboratory, Berkeley, California

Lawrence Livermore National Laboratory, Nevada Test Site, Mercury, Nevada

Los Alamos National Laboratory, Los Alamos, New Mexico

Mound, Miamisburg, Ohio

Oak Ridge Gaseous Diffusion Plant, Oak Ridge, Tennessee

Oak Ridge National Laboratory, Oak Ridge, Tennessee

Pacific Northwest Laboratory, Richland, Washington

Paducah Gaseous Diffusion Plant, Paducah, Kentucky

Pinellas Plant, St. Petersburg, Florida

Princeton Plasma Physics Laboratory, Princeton, New Jersey

Reynolds Electrical and Engineering Co., Nevada Test Site, Las Vegas, Nevada

Rockwell-Hanford Operations, Richland, Washington

Rocky Flats Plant, Golden, Colorado

Sandia National Laboratories, Albuquerque, New Mexico

Sandia National Laboratories, Livermore, California

U.S. DOE-Idaho Operations Office, Idaho Falls, Idaho

U.S. DOE-New Brunswick Laboratory, Argonne, Illinois

Westinghouse Hanford Company, Richland, Washington

Y-I2 Plant, Oak Ridge, Tennessee 


\section{GENERAL INFORMATION}

The purpose of this section of the questionnaire was to determine the number of workers who may experience an intake of radioactive materials and the range of sizes of the facilities' internal-dosimetry programs. Information on the number of individuals who actually experienced an intake of radioactive material was also obtained.

\section{SERVICES PROVIDED}

All of the respondents except one indicated that work is routinely performed with unsealed sources. All respondents, including the facility with no unsealed sources, provide their workers with an internal-dosimetry program and all but one provide an ajr-monitoring/sampiing program. Because all 29 respondents do provide internal-dosimetry services, all were included in the survey,

\section{SIZE OF PROGRAMS}

The internal-dosimetry programs at the responding DOE facilities vary in size over nearly 3 orders of magnitude. In the smaliest program, no workers are routinely exposed to unsealed sources (but five workers are infrequently exposed), while in the largest program, 1491 workers routinely work with unsealed sources of radioactive material and 5300 workers have the potential of being exposed to unsealed sources of radiation. The total number of individuals who routinely work with radioactive materials at the 29 DOE facilities included in the survey is 12,219 , and a total of 33,670 individuals have the potential for exposure to unsealed radioactive sources.

\section{PERCENTAGE OF MAXIMUM DDSE LIMIT RESULTING FROM INTAKES}

The health physics practices at DOE facilities imply that the policy of DOE is that no worker shall routinely inhale radioactive materials (except for tritium). The questionnaire included a question relating to depositions that was intended to determine the effectiveness of this policy and the magnitude of intakes that occur. The number of individuals at each facility who were 
found to have an intake and the percentage of the pertinent annual dose equivalent that resulted are shown in Table 2 . The table lists the radionuclides to which the workers were exposed and the number of workers in each of 11 percentage categories. If the information was provided, the table also lists the number of individuals in each percentage category by radionuclide.

Several factors complicate the interpretation of the table. Some facilities reported the cumulative number of exposures since startup of the facility, others reported the number since the current contractor began operating the facility, and still others reported the number of the previous calendar year. Some contractors have been instructed by their field office that plutonium uptakes exceeding $50 \%$ of the maximum permissible body burden (MPBB) should be reported only the first year the criterion is exceeded and not thereafter. Also, current year whole-body internal-dose commitments, from radionuclides for which the whole body is the critical organ (e.g., exposures to ${ }^{3} \mathrm{H}$ ), are combined with the external whole-body dose, and some contractors keep these whole-body interna]-dose commitments in their internal dosimetry records, but others do not.

Taking these factors into consideration, the data indicate that about $0.4 \%$ of those who routinely work with unsealed radioactivity have had an intake that resulted in more than $50 \%$ of the MPBB. Thus it appears that the implied DOE policy that no worker shall intentionaliy be exposed to airborne radioactive material has produced the desired results. 
TABLE 2. Number of Workers in Percentage Categories of Maximum Uptake

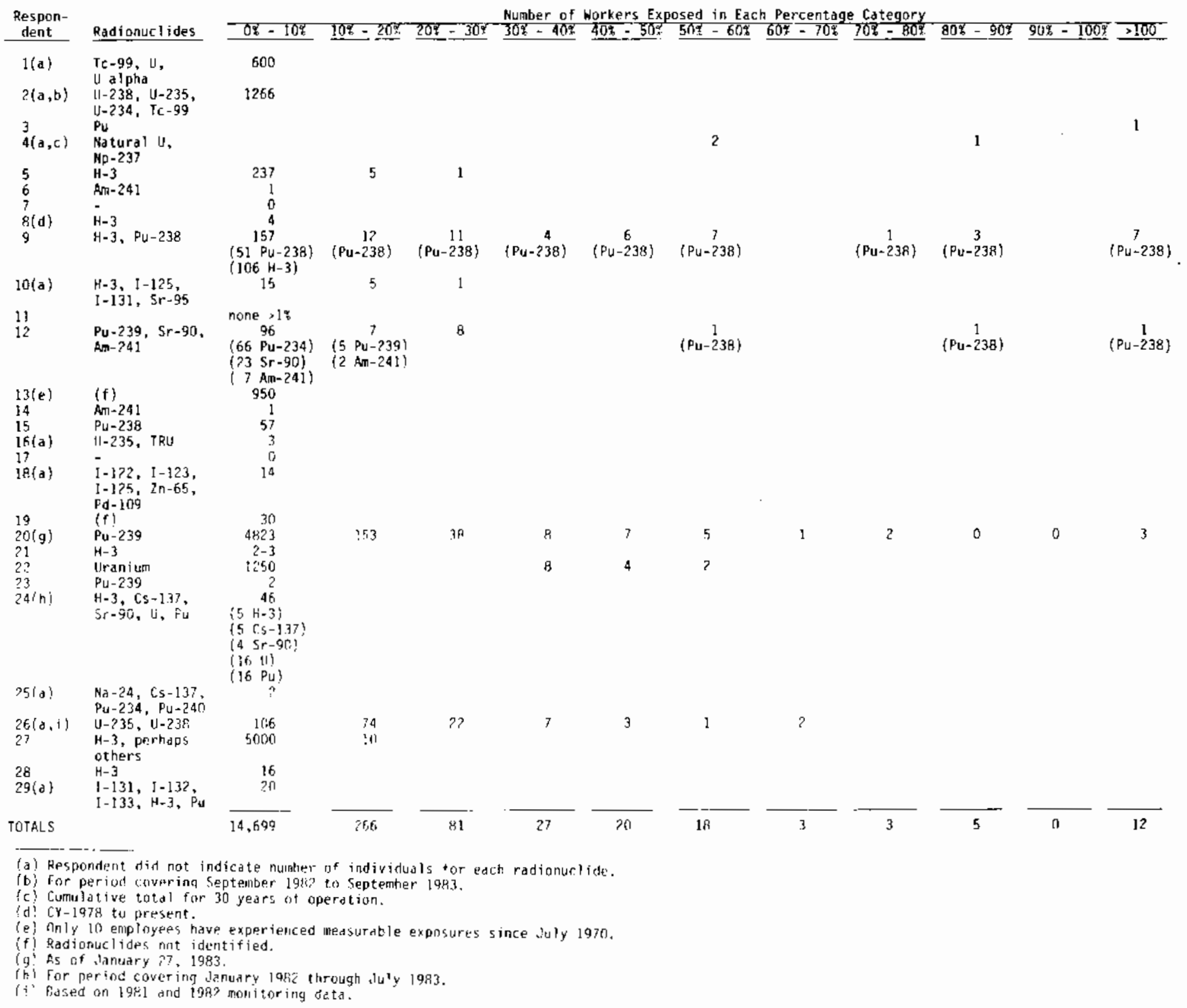




\section{DOCUMENTATION}

The purpose of this section was to determine which aspects of the internaldosimetry program are documented. For the purposes of this questionnaire, the internal-dosimetry program was considered as having four parts: the routine bioassay program, the diagnostic bioassay program, the dose assessment program, and the quality assurance program.

Documentation of the programs varies widely. The routine bioassay programs and quality assurance programs are the most frequently documented, with 19 of 29 respondents indjcating that formal documentation has been prepared for each. The dose assessment methods and the diagnostic evaluation programs are less well documented; the dose assessment methods have been documented at 11 facilities, and the diagnostic evaluation programs have been documented at only eight facilities. Many of the documents cited appeared to be "in-house" manuals rather than documents that have been published for public distribution. The extent of documentation is roughly a function of the size of the program; as the program becomes larger, the documentation becomes more extensive. However, one very iarge program has no formal documentation. One respondent stated that the facility has not documented a diagnostic evaluation program or a dose assessment program because there have been no measurable uptakes. 


\section{BIOASSAY PROCEDURES}

The purpose of this section of the questionnaire was to define the type of internal-dosimetry program at each DOE facility. The questions dealt with the types of bioassays used at the facilities on a routine basis, the scheduling of the routine bioassays, the kinds of diagnostic procedures used, and the number of bioassays performed during the previous year.

\section{BASIS FOR INTERNAL DOSE ESTIMATION}

Routine bioassay programs are conducted by 28 of the 29 participants in this survey. The facilities were asked what data are used as the basis for estimating internal radiation doses. The majority of the respondents rely on indirect bioassay data (i.e., the results of radioassays of excreta, used by 28 of 29 respondents) and direct bioassays (i.e., in-vivo counting, used by 26 of the 29). Approximately one-third of the respondents (9 of 29) indicated that air-monitoring/sampling data are used to assist in providing an estimate of internal depositions of radioactive material; however, none depend solely upon air monitoring/sampling data.

\section{SAMPL ING FREQLEENCY}

The respondents indicated that both the effective half-life of the radioelement and the quantity of radioactive material with which an individual is working influence the sampling frequency for bioassays. One-half (15 of 29) vary the sampling frequency in response to differences in the effective halflife of the radionuclide, while 26 of 29 vary the sampling frequency as a result of the quantity of radioactive material with which an individual is working. The majority of the respondents (26 of 29) report that they sample at intervais that are independent of project schedules. Most respondents (20 of 29) indicated that they perform bioassays at the termination of employment. However, only about half of the respondents indicated that they perform bioassays at the initiation of employment, the initiation of a project invoiving a new radionuclide, or the end of a project (15 of 29,13 of 29 , and 15 of 29 , respectively). The respondent for one facility indicated that work history and job hazard are also considered when determining the sampling frequency. 


\section{NUMBERS AND TYPES OF ASSAYS PERFORMED}

Table 3 lists the number of urine, fecal, and whole-body/lung bioassays performed at the DOE facilities in the last year. The intent of this question was to determine the total number of bioassays performed during the last year. However, the question was placed on the same page as the question concerning diagnostic assays; thus, some of the respondents may have interpreted it as applying to diagnostic assays only. The numbers presented are for the last year for which data are available; it is not known whether that was a typica? year.

The predominant bioassay type was urine assay, with 81,246 assays performed. The next most frequently performed bioassay was whole-body/lung count $(41,278$ assays), and the least frequently performed was fecal analysis $(1,781$ assays $)$. Because of the possible confusion in interpreting the question, these numbers should be considered minima for each bioassay type.

Urine assays are the most commonly employed routine assays and screening tests. Whole-body/lung counts are also used for screening, whereas fecal analyses are used primarily for quantification of known or suspected intakes. Some of the respondents indicated that collecting fecal samples has a detrimental effect upon the morale of the workers. 
TABLE 3. Frequency of Assays Performed in 1982

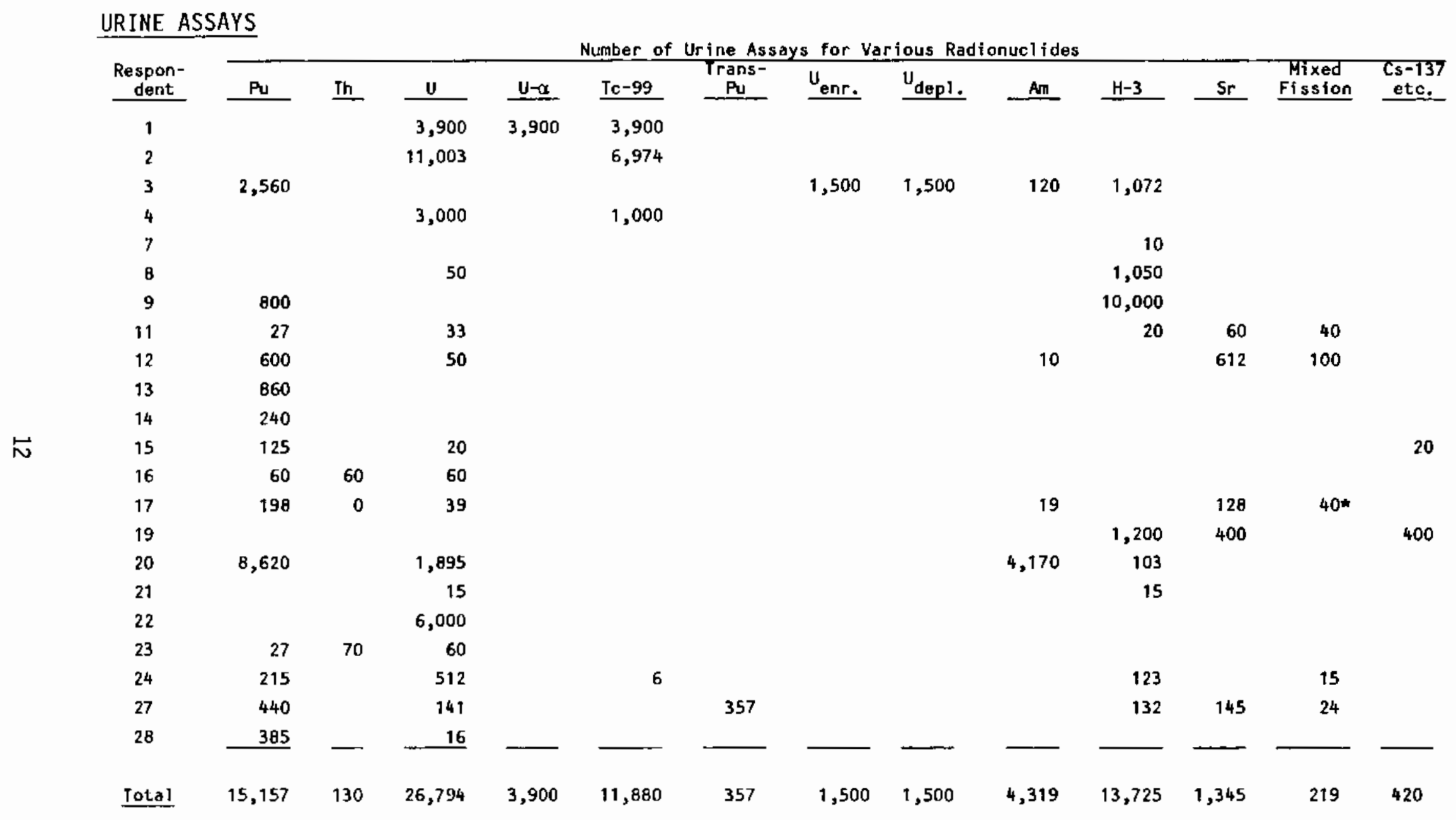

\footnotetext{
- Gamma spectroscopy.
} 
TABLE 3. (continued)

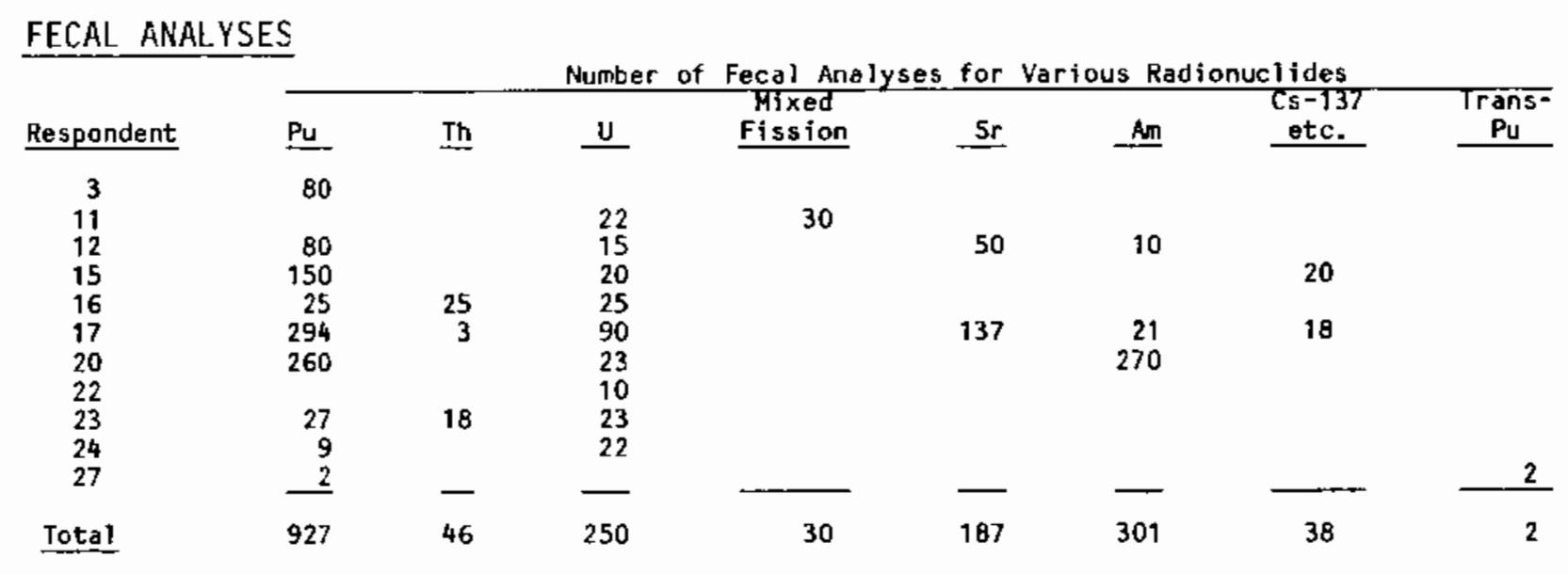

WHOLE-BODY/LUNG COUNTS

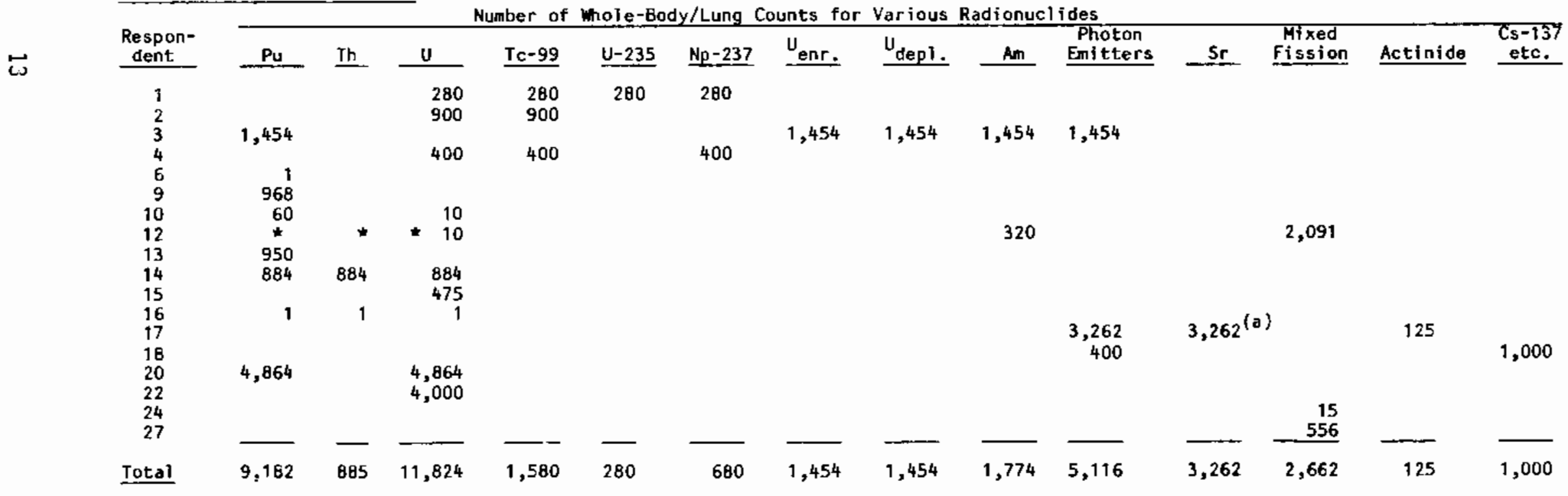

* Use Am as tag.

(a) Skul\} counts. 


\section{DATA ANALYSIS/INTERPRETATION}

The purpose of this set of questions was to determine the greatest extent to which data analysis was performed on bioassay data. Questions about the mathematical models employed were also included to provide information on the methods by which the facilities performed this data analysis.

\section{ANALYSIS/INTERPRETATION}

The question on the extent of data analysis offered five choices:

a) no analysis performed (raw data recorded only)

b) estimate the activity in whole body at time of bioassay or measurement

c) estimate the fraction of MPBB of the radionuclide

d) estimate the activity in critical organ (only)

e) estimate the activity in (several) specific organs.

As shown in Table 4, some respondents marked yes for only one of the five, others marked yes for more than one, and three left the question blank. If it is assumed that the choices listed from (a) to (e) represent an increase in the complexity of data analyses performed, then looking at the most complex choice marked by each respondent gives the following results: one respondent marked that no analysis is ever done; two indicated that the most extensive analysis performed is estimating the activity in the whole body at the time of measurement; two indicated that estimating the percent of the MPBB is the most extensive analysis performed; nine estimate the activity in the critical organ; and 12 estimate the activity in several organs as their most extensive data analysis.

The responses to this question can also be interpreted in light of comments by many respondents that the extent of the data analysis performed in any given situation depends on the data; some respondents stated that the levels (of radioactivity) are normally too low for data analysis. For example, the greater the activity in a urine sample, the more complex the choice of analysis performed. Looking at the multiple responses in Table 4 from this perspective, five respondents indicated that, in a given situation, they may 
TABLE 4. Analysis of Data

Analys is Choices Marked by Each Respondent

Activity in Fraction Activity in Activity in

Respondent Analysis Whole Body of MPBB Critical Organ Several Organs

1

2

3

4

5

6

8

9

10

11

12

13

14

15

16

17

18

19

20

21

22

23

24

26

27

28

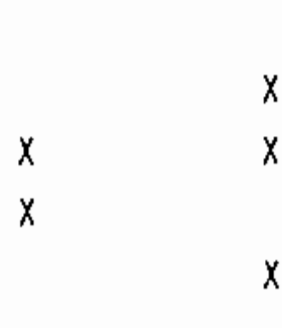

$x$

$x$

$x$

$x$

$x$

$x$

$x$

$x$

$x$

$x$

$x$

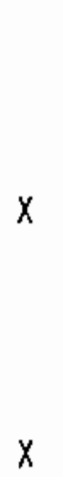

$$
x
$$

$x$

$x$

$x$

$x$

$x$

$x$

$x$
$x$
$x$
$x$
$x$

$x$

$x$

$x$

$x$

$x$

$x$

$x$

$x$

$x$

$x$

$x$

$x$

$x$

$x$ $x$

$x$

$x$

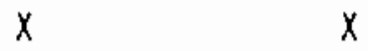

$x \quad x$

$x \quad x$

$x \quad x$

$x$

$x$

$x$

$x$

$x$

$x$

$x$

$x$

$x$

$x$

$x$

$x \quad x$ 
perform no analysis; 17 may estimate the activity in the whole body; 19 may estimate the function of the MPBB; 18 may estimate the activity in the critical organ; and 12 may estimate the activity in other organs.

The question on the interpretation of data was intended to show the extent to which internal-dosimetry data are interpreted. Here again, many respondents commented that the extent of interpretation is dependent upon the data. Most (21 of 29) indicated that they calculate the quantity of intake. For seven of these respondents, calculating the quantity of intake (via back calculation from time of measurement) is the only type of interpretation performed. Thirteen respondents calculate the dose-equivalent rate to the critical organ at the time of measurement, and 13 calculate the dose-equivalent rate to the whole body at the time of measurement. Only six respondents indicated that they calculate the dose equivalent rate to organs other than the critical organ.

A question was included on how the dose for the calendar year is calculated. Two-thirds of the respondents (19 of 29) compute a calendar year dose to the critical organ, and two-thirds (19 of 29) also compute a calendar year dose to the whole body. Ten of 29 respondents indicated that they compute a calendar year dose to individual organs other than the critical organ. The data from this question and the previous question (on interpreting data) show that more facilities compute a calendar year dose than compute dose rates at the time of measurement. This may mean that dose rates are not commonly computed but integrat doses are.

Approximately one-third of the respondents ( 9 of 29) indicated that the 50-year committed dose equivalent to the whole body is calculated for intakes of radioactive material. Three respondents indicated that 50-year committed dose equivalents to specific organs are calculated.

As already noted, comments written on the questionnaires indicated that many of the respondents have various action levels that determine the extent of analysis and intepretation performed. This would imply that much of the data analysis is not automated and is performed on a case-by-case basis. 
HANDLING OF UNKNOWN DATE OF INTAKE

An important consideration in dose assessment is assigning a date of intake when the actual date is unknown. This may occur if an intake is discovered during a routine bioassay procedure but no obvious incident had occurred. Three response choices and an "other" were listed for this question. Nine respondents assign the intake to the day following the last negative count or sample, and eight assign it to the mid-time between the last negative sample or count date and the positive sample or count date. One assumes that the date of intake is the day preceding the positive sample or count. However, 18 respondents marked "other" and described different or additional methods of assigning an intake date. These methods are 1 isted in Table 5. As discussed later in this report, the respondents expressed concern about this problem and would like to have a better way of estimating the date of intake.

\section{METABOLIC MODELS}

The questionnaire also requested information concerning the methodology employed to describe the metabolism of radioelements within the body. Specifically, the respondents were requested to refer to a published document or to describe the method employed. In the event that a published method was employed, the questionnaire asked whether the published model had been modjfied and, if so, how. The questionnaire also asked whether the procedure used is modified to fit individuals and, if so, how.

In the case of plutonium, the respondents estimate the uptake by the body using the equations developed by Langham $(1957,1964)$ and by Langham, Bassett, Harris, and Carter (1950). These equations have been implemented in a computer code, PUQFUA (프느onium Body Burden (Q) From Urine Assays) or its revision PUQFUA2, which is described in LA-7403-H. In the case of uranium, WASH-1251, Application of Bioassay of Uranium, was identified as a source of information for biokinetic parameters. In addition to the above, various respondents offered the following as the models or source of the models used for estimating the uptake of radionuclides: ICRP-2, 10, 10A, 20, 26, and 30; MIRD; reports of the National Council on Radiation Protection and Measurements; Heal th Physics Journal; Journal of Nuclear Medicine; ORNL/NUREG TM-190; 


\section{TABLE 5. Assumptions Made Regarding Unknown Date of Intake}

Respondent

As sumption

Exposure potentials for intake of radiodtive moterials are overwhelmingly associated with highly soluble compounds wich are very rapidly el iminated from the body. The urinalysis results show that exposures are maintained at a small fraction of the permissibie level. No effort is made to relate lom and uniformly transient excretion levels to an equivalent dose.

Mathematical algorithm derived from ICRP 2 Uranium Retention Function used to solve for time of acute soluble exposures.

For Pu, on date of accidental intake when knowm; otherwise, 15 days before sample submission. For U, varying times depending on urine assay results for several samples. For tritium, uptake assumed to occur on day of sample submi ssion.

Exposures of any significance are normally related to a known incident.

Best estimate as to day of actual exposure. We do not have a baseline or routine sampling program to fall back on.

For acute tritium exposures, date of uptake depends upon investigation.

Study of the individual case history attempts to determine a "likely" intake time. If this is not possible, use (c) option [i.e., mid-time between the last negative sample or count date and the positive sampie or count date].

Intake is sometimes arbitrarily assumed to occur 100 days prior to samp?e.

Based on mork history.

Reviem mork history of individual and establish most probable time of intakes.

Health physics logbooks are examined to correlate known release dates with positive bioassay data. This has been done for ram bioassay data recorded during the 1950 's and ' 60 's.

A review will be made of the mork history of the individual during the period in question, and all pertinent air-sampling data will be reviewed. The most ?ikely date will be determined based on that. If no indicator exists, then day following last negative sample will be used.

Dependent on investigation.

Consult with employee and health physicist to obtain best estimate.

It is assumed that intake occurred the day after the individuai's last count.

Comparison with representative excretion curve.

In the case of ${ }^{3} \mathrm{H}$, the assumption of continuous exposure or exposure at short enough intervals to maintain stable or slowly varying body burdens is made. in no other cases have we had the problem.

Relate to programatic activity. 
ORNL/TM-793; and textbooks, specifically that of Hine and Brownel1. Also mentioned were the articles by Bernard (1958) and Beasley, et a1. (1966). Most respondents did not describe the manner in which the above references were used. The usual response was only the name of a report or the name of the journal.

Concerning modifications of methods for individuals, eleven respondents indicated that individual characteristics are taken into account in the estimation of uptakes and radiation doses. Two respondents indicate that individual variations in chest thickness may be used to modify the estimate of activity in the lung following lung counts. Two respondents also indicated that the height and weight of the individual may influence the estimates. The methods by which these modifications are made were not described by the respondents.

The elimination/retention constants of metabolic models are the most commonly modified parameters; nine respondents indicated that the observed rates of excretion or clearance from the body take precedence over published values wherever possible. Two of these respondents indicated that individual biological half-times are computed for every instance of ${ }^{3} \mathrm{H}$ intake and that the actual half-times are used to compute radiation doses. One respondent stated that iung clearance half-times are modified to match observed clearance. Two respondents stated that bioassay data is used to establish elimination rates from specific sites within the body; these rates are used to modify computer code and hand calculations of internal dose. One respondent stated that modifications in dose interpretation are based on the individual excretion rate and effective half-life which are determined by repetitive sampling; the radionuclides for this process were not stated. The other respondents who use observed data to modify excretion/retention parameters did not specify the radioelements for which these modifications are made. One respondent indicated that, for $\mathrm{Pu}$, all samples taken for 100 days after chelation treatments are excluded from the calculation of uptakes.

These responses indicate that individual values for excretion, retention, height, weight, etc. are thought to vary from the "reference values" enough to justify efforts to "customize" estimates of radionuclide uptake and dose assessment. 


\section{QUALITY ASSURANCE}

The purpose of this series of questions was to determine whether the facilities have a formal quality control program, what minimum detection limits are used, and whether the facilities participate in bioassay intercomparison studies.

\section{QUALITY ASSURANCE PROGRAMS}

A1] but four of the respondents indicated that they have a quality assurance program, although, as previously mentioned, only nine of the quality assurance programs have been formally documented.

\section{MINIMUM OETECTION LIMITS}

The responses to the question concerning the minimum detection limits ( $M D L)$ ranged from a table containing two entries to a reply consisting of seven pages and 99 entries. The most commonly reported radionuclides are listed by bioassay technique in Appendix $B$. The radionuclide identifications are in the notations used by the individual facilities.

The MDLs appear to vary considerably among the facilities, although the extent of the differences is hard to quantify, especially for urine samples. The difficuities come from the fact that the reported sample sizes are not the same for all facilities and it is not known whether the given sample size represents a minimum sample required for the stated limit. It is difficult to compare the detection limits for the actinides because there is little uniformity in the definition of the radionuclide groups; for example, plutonium was listed in the following eight ways for urine samples:
- piutonium
- $\operatorname{Pu}(\alpha)$ isotopic
- $239 \mathrm{Pu}$
- PuAm alpha
- $238 \mathrm{Pu}$

$$
\begin{aligned}
& 238,239 \mathrm{Pu} \\
& \text { - } 239,240 \mathrm{Pu}
\end{aligned}
$$$$
\text { - }{ }^{238} \mathrm{Pu}, 239,240 \mathrm{Pu}
$$

As can be seen in the table "Minimum Detection Limits for Uranium Using Urine Assay" (p. B.2), a similar situation exists for uranium. The MDLs also vary for other radionuclides. For example, the MDL for ${ }^{137} \mathrm{Cs}$ in urine varies from 
$30 \mathrm{pCi} / \mathrm{L}$ to $100 \mathrm{pCi} / \mathrm{sample}$, an apparent factor of 3 , and the $\mathrm{MDL}$ for ${ }^{3} \mathrm{H}$ in urine varies from $5 \mathrm{pCi} / \mathrm{L}$ to $20,000 \mathrm{pCi} / \mathrm{L}$, a factor of 4000 .

\section{QUAL ITY CONTROL SAMPLES}

Most of the respondents indicated that quality control samples are used for urine and fecal samples, although some did not state the frequency of their use. The types of quality control samples of interest were blankcheck samples, spiked samples, open-audit samples, and blind-audit samples. The quality control samples had been defined in the questionnaire as follows: blank-check samples are bioassay samples which contain no added radioactivity; spike samples are bioassay samples which contain known constant quantities of radioactivity; open-audit samples are bioassay samples known by the analyst to be audi: samples but the quantity of added radioactivity is unknown to the analyst; and blind-audit samples are bioassay samples unknown by the analyst to be audit samples and by implication the added radjoactivity is also unknown to the analyst. At some facijities, the concept of quality control samples is extended to other types of bioassay procedures, especially whole-body or lung counts. The responses to this question are tabulated in Table 6 .

In response to a question on the extent of participation in bioassay intercomparison studies, 19 of the 29 respondents indicated that they particizate in such studies. 
TABLE 6. Frequency of Use of Quality Control Samples

URINE SAMPLES

\begin{tabular}{|c|c|c|c|c|}
\hline Respondent & Blank & Spiked & Open Audit & Blind Audit \\
\hline 1 & $x^{(a)}$ & $x$ & $x$ & $x$ \\
\hline 2 & $\mathrm{x}$ & $x$ & $x$ & $\mathrm{x}$ \\
\hline 3 & 1 per 16 samples & 1 per 16 & Yes & No \\
\hline 4 & biweekly & samples & weekTy & \\
\hline 6 & & $1 / \mathrm{mo}$ & & \\
\hline 7 & $x$ & $x$ & $x$ & \\
\hline 8 & each run & each run & & \\
\hline 10 & $10 / y r$ & $25 / y r$ & & \\
\hline 11 & $10 / \mathrm{mo}$ & $15 / \mathrm{mo}$ & $22 / \mathrm{mo}$ & $3 / \mathrm{mo}$ \\
\hline 12 & $10 / \mathrm{mo}$ & $15 / \mathrm{mo}$ & $22 / \mathrm{mo}$ & $3 / \mathrm{mo}$ \\
\hline 13 & 10/mo & $15 /$ mo & $22 / \mathrm{mo}$ & $3 /$ mo \\
\hline 14 & $10 / \mathrm{mo}$ & $15 /$ mo & $22 /$ mo & $3 /$ mo \\
\hline 15 & each set of samples & & $2 \%$ of samples & \\
\hline 16 & each set of samples & & $2 \%$ of samples & \\
\hline 17 & each set of samples & & $2 \%$ of samples & \\
\hline 18 & & $x$ & $10 \%$ & \\
\hline 20 & $\begin{array}{l}1 \text { per } 15 \text { samples } \\
\text { (daify) }\end{array}$ & & & $\begin{array}{l}1 \text { per } 15 \\
\text { sample (daily) }\end{array}$ \\
\hline $\begin{array}{l}21 \\
22\end{array}$ & $\begin{array}{l}\text { each sample series } \\
500 / y r\end{array}$ & $500 / y r$ & & every quarter \\
\hline $\begin{array}{l}23 \\
24\end{array}$ & $\begin{array}{l}x \\
\text { monthly }\end{array}$ & $\begin{array}{l}x \\
\text { monthly }\end{array}$ & & \\
\hline 27 & & 1.0 & & \\
\hline 28 & $3 \%$ & $3 \%$ & $3 \%$ & $3 \%$ \\
\hline 29 & $3 \%$ & $3 \%$ & $3 \%$ & $3 \%$ \\
\hline
\end{tabular}

(a) $x$ indicates that the sample type is used but no frequency was stated.

\section{FECAL SAMTLFS}

Respondent

Blank
N/A
each set of samples
each set of samples
eachy set of samples
$x$ per 5 samples
1 per
$x$
monthly

\begin{tabular}{|c|c|c|}
\hline Spiked & Open Audit & BTind Audit \\
\hline$N / A$ & $\begin{array}{l}\text { N/A } \\
2 \% \text { of samples } \\
2 \% \text { of samples } \\
2 \% \text { of samples }\end{array}$ & $\mathrm{N} / \mathrm{A}$ \\
\hline $\begin{array}{l}x \\
\text { (b) } \\
x \\
\text { monthly }\end{array}$ & $x$ & $x$ \\
\hline
\end{tabular}

(a) $x$ indicates that the sample type is used but no frequency was stated. (b) Internal standard. 
TAELE 6. (continued)

\begin{tabular}{|c|c|c|c|c|}
\hline Respondent & Biank & Spiked & Open Audit & Blind Audit \\
\hline 2 & performed by other & & in-vivo & whole body \\
\hline 15 & $\begin{array}{l}1-3 \text { background } \\
\text { counts/day }\end{array}$ & (a) & & \\
\hline 16 & $\begin{array}{l}\text { 1-3 background } \\
\text { counts/day }\end{array}$ & (a) & & \\
\hline 17 & $\begin{array}{l}\text { every clean person } \\
3 / \text { day }\end{array}$ & & $x^{(b)}$ & \\
\hline 24 & $\begin{array}{l}\text { intercomparison as } \\
\text { available/standards, } \\
\text { blank approximately } \\
\text { monthly }\end{array}$ & & & \\
\hline 28 & 3\% (split samples) & & & \\
\hline
\end{tabular}

(a) Energy check 1/day, every 2-3 weeks a complete instrument check.

(b) $x$ indicates that the sample is used but no frequency was stated.

LUNG COUNT

\begin{tabular}{cl} 
Respondent & \multicolumn{1}{c}{ Blank } \\
3 & $\begin{array}{l}2 / \text { wk } \\
\text { intercomparison as } \\
\text { available/standards, } \\
\text { blank approximately } \\
\text { monthly }\end{array}$
\end{tabular}

AUTOPSY TISSUE

$\begin{array}{llll}\text { Respondent } & \frac{\text { Blank }}{20} & \frac{\text { Spiked }}{\text { I per } 8 \text { samples }} & \text { Open Audit } \\ \begin{array}{l}\text { Internal } \\ \text { standard }\end{array} & \begin{array}{l}\text { Beef tissue } \\ \text { with Pu-234, } \\ \text { Am-241, U-234, } \\ \text { U-238 }\end{array}\end{array}$




\section{AIR-MONITORING/SAMPLING PROGRAM}

The purpose of this section was to obtain a Timited amount of information concerning the air-monitoring/sampling program and how the data from this program was utilized by the internal-dosimetry programs.

GENERAL INFORMATION

ATl but one of the respondents indicated that an air-monitoring/sampling program is provided for the workers. Three of these indicated that only air samplers are provided; the rest provide both monitors and samplers.

\section{LOCATIONS OF MONITORS/SAMPLERS}

The most prevalent location for air monitors/samplers is the center of the work area room (used by 18 of 28 respondents). The next most commoniy used locations are the work area exhaust vent, the giove box face, and the hood face, which are used by 17,16 , and 15 respondents, respectively. Seven facilities utilize lapel samplers. Fourteen place monitors/samplers at locations not specifically listed in the questionnaire. These other locations are Tisted in Table 7 .

\section{DATA UTILIZATION}

Four respondents indicated that the results of air monitoring/sampling are routinely placed in personnel files. Each of the facilities records the data in a slightly different way. For example, respondent 7 records total activity inhaled $\left(\mu \mathrm{Ci} / \mathrm{m}^{3} \times\right.$ breathing rate $\mathrm{x}$ time); respondent 14 records, if an accident, ${ }_{\mu} \mathrm{Ci} / \mathrm{m} /$ time; respondent 26 records the $8-\mathrm{hr}$ integral air concentration in alpha $d / m^{3} / m^{3}$. The fourth respondent did not state how the data are recorded.

Health physicists at four facilities have compared the results of their bioassay program and their air-monitoring/sampling program. Poor or little correlation between the two sets of data (no correlation numbers were given) was found at two facilities. At the other two facilities the results of the two programs were found to compare favorably; most exposures were below 
TABLE 7. Auxiliary Locations of Air Samplers/Monitors

Respondent

1

2

4

6

11

12

14

15

22

23

25

26

28

29
Auxiliary Locations

Generally in work area in close proximity to operations conducive to the release of airborne materials.

Work stations.

Breathing zone of the worker.

Tunnel enclosures; tunnel service buildings.

Job sampling requires placement at the area of concern.

Portable CAMs for special jobs, particularly for "greenhouse" work.

Varies with each room - the sampling program is designed to fit the work being done.

Corridor.

Near specific operations.

By working area for non-routine (specia1) operations. By lab exit/entrance for routine monitoring.

Throughout the work areas and at high-potential-release areas. General processing area.

Drill rig platforms, tunnels and other ...

Work area.

detectable limits. No correlation coefficients were given nor were report numbers quoted, which may indicate that the comparisons performed were not statistically rigorous. One respondent indicated that the data from the two programs are currently being analyzed and compared and that the comparison looks favorable; however, the same respondent indicated in the comments section that air sampling is too inaccurate to be acceptable for internal dosimetry for individuals. From this response, it seems that air monitoring may be useful for gross estimations of intake or as a signal that intakes may have occurrec, but that they are not useful for estimating the amount of radioactive material inhaled by an individual. 


\section{RECORDS}

The purpose of this section was to obtain information concerning the recordkeeping systems for internal-dosimetry data at DOE facilities. The intent was to learn what information could be retrieved if epidemiological studies were to be performed on internal uptakes of radioactive materials. Specifically, there was an interest in learning whether the data recorded are sufficient to reevaluate an individual's internal-dose history. The location and form of the records was not considered important compared to the existence of the records. The questions were based upon the reconmendations in Standard N13.6 of the American National Standards Institute (ANSI 1972).

The respondents generaliy record the information listed on the questionnaire. The 50-year weighted dose commitment is recorded by only six respondents; however, there are no requirements to record this quantity. Several of the respondents may not record sufficient information in the personne] dosimetry files to allow re-estimation of radiation doses in a timely fashion. In the introduction to the records system section of the questionnaire, it was clearly stated that the question was whether records were present and readily accessible. It is not known whether a 11 respondents answered in this spirit however. Table 8 lists the responses received; the number of facitities which record various combinations of the items are listed on the same table. The results of this questionnaire agree well with the results reported by Fix et at. in 1981 .

A11 but two of the respondents record the radionuclides deposited. One of the two has stated that the internal-dosimetry program is nascent and the recordkeeping system is not yet developed.

The excreta data for the radionuclides is kept by all but four of the respondents. One of these four indicated that internal-dosimetry services are subcontracted to another respondent in the survey who does keep excreta data. Two of the remaining three respondents have no employees who are routinely exposed to radioactive material, while at the final respondent's facjlity there appears to have been no major uptakes in the last 5 years. Two of the 
IABLE 8. Parameters Included in Personnel Dosimetry Systems

Parameters Used

a) Nuclides of potential uptake

b) Schedule for routine bioassay

c) Respirator fit test data

d) Respiratory protection factor

f) Radionuclide deposited

g) Body burden

h) Primary organ of deposition

i) Organ burden

j) Estimated date of deposition of radionuclides

k) Annual dose from internal deposition

1) Sum of external and internal doses (for year) (effective annual dose commitment)

m) Nuclide excretion data

n) Method of detection (e.g., air monitoring/sampling, in-vivo testing, urine or fecal analyses)

o) 50-year weighted dose commitment $\begin{array}{r}\text { Number of }(a) \\ \text { Respondents } \\ \hline\end{array}$

21

23

25

20

27

20

22

21

20

22

14

25

27

6

Combinations of Parameters Included in Personnel Dosimetry Systems Combinations of Parameters Number of Respondents (a)

g or $i$

$j, m$, and $n \quad 20$

$j, m, n$, and $g$ or $i \quad 18$

$g, i, j, m, n$

$g, i, j, k, m, \pi \quad 17$

$f, g, j . j, k, m, n \quad 17$

(a) Total number of respondents is 29 . 
respondents apparently rely on recorded excreta data; they indicated that no records are kept for either body burdens or doses from internally deposited radionuclides.

Finally, the responses may reflect the distribution of recordable exposures more accurately than the state of recordkeeping; for example, two respondents indicated that no records have been kept because no significant uptakes have occurred; if an uptake were detected, then all records would be maintained. The responses indicate that, at present, sufficient data are recorded to support epidemiological studies requiring estimates of radiation doses from radioactive materials taken up by the body at about two-thirds of the responding facilities. 


\section{COMMENTS RECEIVED}

The questionnaire contained a section that requested the comments and concerns of the individuals responsible for internal dosimetry, and most respondents did take the time to provide comments. The section contained questions that could serve as the basis for response on topics such as the state of the art of internal dosimetry, its capabilities and limitations, and the perceived needs for improvement, if any. The full text of the questions is listed with the questionnaire in Appendix A. Some of the respondents answered each question in turn, while others discussed internal dosimetry without specifically addressing the questions. In either format, the comments provided valuable insight into the current state of internal dosimetry. Specific items of concern mentioned by the respondents were mathematical models, detection methods, the assignment of an exposure date, and the difficulty in establishing the physical/chemical form of the deposited radionuclides.

\section{SOURCES OF ERROR}

The first question in the comments section asked what the respondents thought were the greatest source of error in internat dosimetry. The sources of error identified were:

- errors in identifying the date of exposure

- the mathematical models used to estimate the uptake of radioactive material, especially the variability in actual excretion patterns, which are difficult to fit to a model

- insufficient information concerning the chemical/physical form of the deposited material

- difficulties in estimating the intake in the presence of residual skin contamination.

The uncertainty in assigning a date to an exposure when the actual date is not known was a frequently mentioned item of concern. This concern is greatest for radioelements that have a short effective half-life within the body, because small errors in the estimated date of intake can result in large 
errors in the back-calculated estimation of the quantity of material taken into the body.

The mathematical models used for estimating the uptake of radioelements and the consequent internal doses were also mentioned frequently as sources of error. The respondents observed that for some radionuclides ( ${ }^{99}$ Tc was specifically mentioned) too many assumptions are made about the metabolic pathways. Also, the values of metabolic parameters are recognized as varying among individuals, but the models cannot readily be modified for individual characteristics. One respondent expressed concern that the metabolic parameters in a given individual change with time. The changes could occur as a result of medical intervention (e.g., chelation therapy), disease, and the normal aging process (e.g., bone remodeling). The models described by ICRP do not consider changes in the values of metabolic parameters with time. One respondent questioned whether the bioassay data is accurate enough to allow distinction among different metabolic models.

The physical and chemical form of the radioelement taken into the body has a strong influence upon the time-dependent distribution of the material within the body. The metabolic model described in ICRP-30 assumes that the particle size and solubility class of inhaled particulates are known and that these factors can be used to modify the estimated retention of particulates by the lung. The comments received indicate that in many cases these parameters are not known and that learning these values is not a simple task. Also, in the case of enriched ${ }^{235} \mathrm{U}$, the amount of uranium corresponding to a maximum permissible Tung burden varies with the enrichment. The level of enrichment of uranium in the lung of a worker is difficult to quantify accurately. One respondent indicated that as part of estimating the uranium enrichment, ${ }^{238} \mathrm{U}$ must be measured. Measurement of ${ }^{238} \mathrm{U}$ in the lungs is based on the ${ }^{234} \mathrm{Th}-{ }^{234} \mathrm{Pu}$ daughters and large errors can be obtained if the parent ${ }^{238} \mathrm{U}$ is not in equilibrium with its progeny ${ }^{234} \mathrm{Th}-{ }^{234} \mathrm{Pu}$.

Several concerns were expressed regarding the ability to detect and quantify the amount of radioactive material in the body. One concern is the interference caused by contamination on the outside surface of the exposed individual. This problem is most acute when the ievel of skin contamination 
is below the detection limit of instruments used to quantify skin contamination and the quantity of radiaactive material within the body is small. Also of concern is the limited ability to ascertain which organ within the body contains the radioactive material being quantified. This last concern may become very important if the radionuclide content in each of several organs of the body is to be determined and weighting factors applied to the computed organ dose.

\section{IMPRDVEMENTS NEEDED}

The second question in the comments section asked about the aspects of internal dosimetry in greatest need of improvement. The responses indicated that improvements are needed in twa major categories: detection methods (for direct bioassay procedures) and retention/excretion models.

The respondents appear dissatisfied with their ability to perform direct bioassay, especially for alpha emitters in general and all isotopes of uranium and plutonium in particular. The need for improved detection abilities will

become more acute as plutonium free of ${ }^{241}$ Am becomes available. Further, improved direct detection methods may decrease the dependence upon modeling.

Other respondents stated that improvements are necessary in modeling the retention and excretion of radioelements. Specifically mentioned was a need to remove the discrepancies between the uranium retention models presented in ICRP-2 and ICRP-30. A way is also needed to adjust for the metaboic variations among individuals that affect both excretion patterns and the distribution of radioelements among organs. Individual variations in excretion patterns, and the problem of matching those patterns to the patterns predicted by excretion models, were recurrent themes in the comments of the respondents. One respondent stated that the uncertainty of the parameters used in the metabolic models should be stated.

\section{RADIONUCLIDES THAT CAUSE DIFFICULTIES}

The radionuclides that were identified by each respondent as causing the most difficulties were, in most cases, the very radionuclides that the respondent's internal dosimetry program was required to monitor. However, the radionuclides listed and any reasons given for the difficulty may provide 
insight into research needs. Uranium and ${ }^{99}$ Tc were identified as problems because of their highly transient nature (i.e., urine samples for these radioelements tend to be positive for only a few days after an exposure). Plutonium, and specifically the two isotopes ${ }^{238} \mathrm{Pu}$ and ${ }^{239} \mathrm{Pu}$, were listed as difficult to monitor because the low energy and infrequent emission of decay photons makes them difficult to detect outside of the body. One respondent stated that detection and/or quantification of plutonium in the lung is difficult if the worker has also had an uptake of fission products, for example ${ }^{137} \mathrm{Cs}$. Thorium-230 and the actinides in general were also listed as difficult to detect.

\section{ADEQUACY OF INTERNAL DOSIMETRY FOR EFFECTIVE DOSE EQUIVALENT}

The fourth sample question asked whether the current state of internal dosimetry is adequate for estimating effective dose equivalents and, if not, what improvements would be necessary to make it so. Ten respondents answered this question, and eight of these indicated that the current state of internal dosimetry is not adequate.

These eight respondents had an identical underlying reason. The computation of an effective dose equivalent implies that there is adequate knowledge of the dose to 11 different organs at risk and that the weighting factors are properly assigned. The respondents indicated that the first premise (that the dose to 11 organs is known) is false because we are currently unable to directly measure the organ content and because our retention/ excretion models are inadequate.

One of the remaining two respondents thought that the computation of an effective dose equivalent for iodine (in the thyroid) and ${ }^{3} \mathrm{H}$ (in the whole body) may be meaningful. In the case of transuranics, the validity of the weighting numbers was questioned. The last respondent was of the opinion that weighted whole-body dose equivalents have use only as best-estimate numbers.

PROGRAMMATIC REQUIREMENTS FOR EFFECTIVE DDSE EQUIVALENT DR COMMITTED EFFECTIVE DDSE EQUIVALENT

The final question of the comments section requested the respondents to identify the programmatic enhancements required to estimate an effective 
dose equivalent or a committed effective dose equivalent. Six responses were obtained to this question. Two respondents indicated that they are either al ready estimating a weighted whole-body dose equivalent, or could do so with slight modifications in bookkeeping.

Two of the respondents indicated that decreases in detection errors and improvements in detection limits would be required. One of these respondents also indicated the need for strictly defining the organs or systems involved, perhaps in reference to the requirement that doses be computed for the five organs having the highest doses in addition to the gonads, breast, red bone marrow, lung, thyroid, and bone surfaces.

The final two respondents indicated that appropriate computer software should be developed. An example of a usefut computer program would be an interactive program to provide estimates of uptake based on bioassay results.

GENERAL

Many of the respondents did not base their comments on the sample questions but chose instead to provide general comments. However, their comments tend to reinforce those based on the questions.

The respondents appear most confident in their routine bioassay programs. However, even here they are not satisfied with their detection limits.

There is less confidence in diagnostic programs, where the respondents are dependent upon retention/excretion models that they feel are inadequate. Some of these models, such as the Langham equations for plutonjum, are used to estimate the quantity taken into the body, and other models are employed to estimate the radiation dose to the individual. The major complaint concerning the models is, as mentioned earlier, that they cannot be readily modified to match an individual's excretion pattern. Another source of concern, also mentioned before, is the difficulty of quantifying the lung/body burden of radioelements such as uranium and plutonium. Also, the respondents expressed less confidence in their diagnostic assays because they have less experience performing the diagnostic procedures. As seen in Table 2, fewer than $1 \%$ of employees at DOE facjlities may have had an uptake of radioactive material which results in more than $50 \%$ of an MPBB. 


\section{RECOMMENDATIONS FOR IMPROVING INTERNAL-DOSIMETRY PRACTICES}

As a result of the information obtained from this questionnaire, the following recommendations are made:

- Uniform bioassay procedures and records of bioassay results, especially for uranium and plutonium, should be required.

- More sensitive procedures for direct-bioassay measurements should be developed for select radionuclides. Detection limits of direct bioassay methods should be improved for selected radionuclides.

- The development of interlaboratory information interchange shouid be formally promoted in order to best utilize the expertise developed at each laboratory. A manual of good practice for internaldosimetry procedures should be developed for use by all DOE facilities to ensure uniform measurement and evaluation of uptakes.

- Models that can be modified to fit individual excretion patterns should be developed to assist in establishing the amount of radioactive material taken into the body. Interactive computer implementation of the models should also be developed.

- Air-monitoring/survey readings and bioassay data should be studied in order to determine if any meaningful relationship exists. Uniform and simple techniques to determine parrticle size and solubility of inhaled materials should be developed.

\section{UNIFORM BIOASSAY PROCEDURES AND DATA RECORDING}

As mentioned in the section on minimum detection limits, there are eight different ways of describing urine assays for both plutonium and uranium at DOE facilities. Whether, and to what extent, these different methods are comparable to each other is not known. The fact that there are eight ways of describing the analysis for plutonium implies that there are eight different methods of analyzing urine for Pu content and likewise there are eight different methods of dose interpretation based upon those analyses. If a 
similar situation, i.e. great variability among DOE facilities, exists for all radionuclides, then the ability to share improvements in either the bioassay procedures or interpretation of the procedures is greatly hampered.

In addition to reporting data for (possibily) different types of assays, DOE facilities were found to record data on internal depositions in a variety of ways. For example, one facility indicated that records of radionuclides deposited and nuclide excretion data are kept, but that data on organ or body burdens or estimated doses is not kept. Other facilities, however, maintained records of radionucljdes deposited, body burdens, primary organs of deposition, organ burdens, assumed dates of deposition, radionuclide excretion data, and methods of detection.

The difference in the recording methods has two drawbacks: 1) it inhibits the deveTopment of a DOE-wide method of bioassay and dose interpretation; 2) it would cause confusion if epidemiological studies were conducted. The various reporting systems also indicate that the data are collected in different ways. Standard methods of data collection and reporting should be employed. A DOE ad hoc committee on internal dosimetry, comprised of individuals from severai DOE facilities, should be appointed to develop uniform methods for data collection and reporting.

\section{SENSITIVE DIRECT-BIOASSAY PROCEDURES}

The most desirable method for determining the radioelement content of an organ is via direct counting of the organ. However, current direct-bioassay procedures are not adequately sensitive for radionuclides that do not emit high-energy photons in great abundance. A good example of a radionuclide that is difficult to quantify is ${ }^{239} \mathrm{Pu}$. Increasing the sensitivity of direct bioassay for these radionuclides should be a high priority, because newly developed methods of producing ${ }^{239} \mathrm{Pu}$ devoid of the tracer ${ }^{241}$ Am will require that depositions of ${ }^{239} \mathrm{Pu}$ be quantified based solely upon the detection of ${ }^{239} \mathrm{Pu}$.

\section{DOE INTERLABORATORY INFORMATION INTERCHANGE}

From the data presented, it is apparent that the experience of internaldosimetry groups in performing dose evaluations will vary among DOE facilities 
because of differences in the frequency of uptakes and in the radionuclides requiring evaluation. It is also apparent that the bioassay and dose assessment procedures will vary among the facilities. The result of these variations is that there may be differences among the various facilities which are sufficient to inhibit the universal implementation of advances in internal dosimetry procedures that have been developed at DOE facilities. The collective experience and expertise at the various DOE facilities should be available to all DOE facilities. At present, information is shared primarily on an informal basis. The sharing should be made more formal by the establishment of a DOE internal-dosimetry working group, provision of internal dosimetry short courses or seminars, and the development of a manual of good practices.

The manual of good practice could contain guidelines for the basic design of an acceptable internal dosimetry program. The guidelines could include guidance concerning the kinds of bioassay procedures (direct or indirect bioassay) which should be performed for particular radionuclides; the equipment required to perform the procedure, the minimal frequency for performing the procedures perhaps as a function of the quantity of radioactive material avajlable for release, methods to interpret the bioassays and recommended dose assessment techniques. The information interchange can also be implemented by the establishment of interlabortory quality control efforts such as bioassay intercomparison studies.

\section{DEVELOPMENT OF MODELS AND INTERACTIVE COMPUTER CODES}

The models employed for estimating uptakes are not sufficiently accurate to handle advanced concepts such as the computation of effective dose equivalents. At this time, it is not known whether the models should be reformulated or whether the need is more simply the development of computer codes capable of modifying the values of the kinetic parameters based on an individual's excretion and retention of radioelements. A DOE ad hoc committee on internal dosimetry should be appointed to study the currentiy employed models and computer implementations of the models and to provide suggestions for improvements. 


\section{AIR-MONITORING/SURVEY INVESTIGATION}

Efforts should be made to increase the value of data from air-monitoring/ survey instrumentation. Data from air-monitoring/sampling instrumentation could be used to help the occupational health physicist evaluate internal deposits of radioactive nuclides. There are nine facilities who use airmonitoring/sampling results for estimating depositions of radioactive materials in workers and four of these routinely record the data in the personnel files or who have the data readily available. This small fraction of facilities who actualiy attempt to use the data indicates that the data may not be considered valuable. Possible improvements may include the ability to collect samples that may be tested for particle size, solubility of the aerosols in body fluids, and isotopic composition. 


\section{REFERENCES}

Alexander, R. E. I974. Application of Bioassay of Uranium. WASH-1251, U.S. Atomic Energy Commission, Washington, D.C.

American National Standards Institute (ANSI). 1972. American National Standard Practice for Occupational Radiation Exposure Records Systems. ANSI NI3.6-1966 (rev. 1972), New York.

Beasley, T. M., H. E. Palmer and W. B. Nelps. 1966. "Distribution and Excretion of Technetium in Human." Health Physics Journal, 12:1425-1435.

Bernard, S. R. 1958. "Maximum Permissible Amounts of Natural Uranium in the Body Air, and Drinking Water Based on Experimental Data." Health Physics Journal, $1: 288$.

Fix, J. J., J. M. SeTby, and E. J. Vatlario. 1981. Current Personnel Dosimetry Practices at DOE Facilities. PNL-3538, Pacific Northwest Laboratory, Richland, washington.

Hine, G. J., and G. L. Brownell, eds. 1956. Radiation Dosimetry, Academic Press, New York.

Killough, G. G., D. E. Dunning, Jr., S. R. Bernard and J. C. Pleasant. 1978. Estimates of Internal Dose Equivalent to 22 Target Organs for Radionuclides Occurring in Routine Releases from Nuclear Fuel Facilities. ORNL/NUREG/ TM-190, Oak Ridge National Laboratory, Oak Ridge, Tennessee.

International Commission on Radiological Protection (ICRP). 1959. Report of Committee II on Permissible Dose for Internal Radiation. ICRP 2, New York.

International Commission on Radiological Protection (ICRP). 1968. Evaluation of Radiation Doses to Body Tissues From Internal Contamination Due to Occupational Exposure. ICRP 10, New York.

International Commission on Radiological Protection (ICRP). 1971. The Assessment of Internal Contamination Resulting From Recurrent or Prolonged Uptakes. ICRP 10A, New York.

International Commission on Radiological Protection (ICRP). 1973. Alka7ine Earth Metabolism in Adult Man. ICRP 20, New York.

International Commission on Radiological Protection (ICRP). 1977. Recommendations of the International Commission on Radiological Protection. ICRP 26, New York.

International Commission on Radiological Protection (ICRP). 1979. Limits for Intakes of Radionuclides by Workers. ICRP 30, New York. 
Langham, W. H. 1957. "The Application of Excretion Analysis to the Determination of Body Burden of Radioisotopes." Brit. J. Radiol. Suppl. 7, 95-113.

Langham, W. H. 1964. "Physiological Properties of Plutonium and Assessment of Body Burden in Man." In Assessment of Radioactivity in Man, Vol. II, p. 565-581, Vienna. IAEA 1964.

Langham, W. H., S. H. Bassett, P. S. Harris and R. E. Carter. 1950. Distribution and Excretion of $\mathrm{Pu}$ Administered Intravenously to Man. LA-1151, Los Alamos National Laboratory, Los Alamos, New Mexico.

Lawrence, U. N. P. 1978. A History of PUQFUA, Plutonium Body Burden (Q) from Urine Assays. LA-7403-H, Los Alamos Scientific Laboratory, Los Alamos, New Mexico.

Seagren, H. A. 1964. Some Developments in Engineering, Fabrication, and Field Support of Laboratory Programs, Report 3. ORNL/TM-793, 0ak Ridge National Laboratory, Oak Ridge, Tennessee.

Wylie, K. F., W. A. Bigler and G. R. Grove. 1963. "Biological Half-Life of Tritium." Health Physics Journal, 9(4):911-914. 
. 
APPENOIX A

QUEST IONNAIRE ON CURRENT INTERNAL-DOSIMETRY

PRACTICES AT DOE FACILITIES 


\section{QUESTIONNAIRE ON CURRENT INTERNAL-DOSIMETRY \\ PRACTICES AT DOE FACILITIES}

\section{TERMINOLOGY}

In this questionnaire the following definitions will apply:

Internal-Dosimetry Refers to all aspects of estimating the radiation dose Program:

Bioassay: and/or dose commitment from radioactive material taken into the body. This includes collection and anaTysis of bioassay samples, in-vivo counting, and evaluation of data. Internal dosimetry may also compute the sum of radiation doses from external and internal sources of radiation.

Refers to all measurements taken to estimate the quantity of radioactive materiai in the body. This includes both indirect bioassay, the radioanalysis of body fluids and excreta, and direct bioassay, the in-vivo counting of the individuat.

Blank-Check Sample: Bioassay samples which contain no added radioactivity; used for quality control.

Blind-Audit Samip?es: Bioassay samples unknown by the analyst to be audit samples and by implication the added radioactivity is aiso unknown to the analyst; used for quality control.

Deposition: The permanent-semipermanent placement of radioactive material in a body organ.

Diagnostic Evaluation: Evaluations performed to determine the location and amount of deposition, used to provide data necessary for estimating internal dose rates. May be locally defined to be identical to a special study.

Intake:

The amount of radioactive material taken into the body. 
Open-Audit Samples: Bioassay samples known by the analyst to be audit samples but the quantity of added radioactivity is unknown to the analyst; used for quality control.

Routine:

That which follows an established pattern or procedure.

Spjked Samples:

Bioassay samples which contain known constant quantities of radioactivity; used for quality control.

Uptake:

The amount of radioactive material transferred to body fluids. 
SECTION I. GENERAL

1. At your facility, is work performed with unsealed radioactive sources?

LEFT

YES NO BLANK

$[28][1]$

2. Is an internal-dosimetry program provided for the workers?

[ 29] [ ]

3. Is an air-monitoring/sampling program provided for the workers?

4. How many personnel routinely work with unsealed radioactive sources at your facility? 12,219

5. How many personnel have the potential for exposure to unsealed radioactive sources at your facility? 33,670

6. Please indicate the number of intakes which resulted in the listed percentage of the pertinent annual dose-equivalent standard as set forth in DOE Order 5484.1, Chapter VI.

\begin{tabular}{l}
$\begin{array}{l}\text { Percentage of pertinent } \\
\text { annual dose-equivalent } \\
\text { standard }\end{array}$ \\
\hline $0-10$ \\
\hline $10-20$ \\
\hline $20-30$ \\
\hline $30-40$ \\
\hline $40-50$ \\
\hline $50-60$ \\
\hline $70-80$ \\
\hline $80-90$ \\
\hline $90-100$ \\
\hline$>100$ \\
\hline
\end{tabular}


SECTION II. DOCUMENTATION

1. Has the routine bioassay program been formally documented?

YES NO BLFT

Please specify document number(s) or title(s)

[ 19] [ 8] (2)

2. Has the diagnostic evaluation program been

formally documented?

$[10][16](3)$

Please specify document number(s) or title(s)

3. Have the dose assessment methods been formally documented?

$[13][14](2)$

Piease specify document number(s) or title(s)

4. Has the quality assurance program been formally documented?

$\left[\begin{array}{ll}19\end{array}\right]\left[\begin{array}{ll}7 \\ \text { ( 3) }\end{array}\right.$

Please specify document number(s) or title(s) 


\section{SECTION III. BIOASSAY PROCEDURES}

The purpose of this section is to define the type and magnitude of your internal-dosimetry program.

1. Is the estimation of internal deposition of $\begin{array}{lll}\text { YES } & \text { LEFT } \\ & \text { BLANK }\end{array}$ radioactive material based on: (check all that apply)
a) air-monitoring/sampling data
[ 9] [ 18]
b) direct-bioassay data (i.e., in-vivo counting)
[ 26] [ 2]
c) indirect-bioassay data (i.e., radioassay)
[ 28$]\left[\begin{array}{ll}1\end{array}\right]$

2. Does your company conduct a routine bioassay program?

[ 1] N0: Go to question 5, this section.

[28] YES: Please list the types of bioassay procedures you do perform routinely, e.g., urine analysis, specific organ counting.

Bioassay Procedure

e.g. whole-body counting
Radionuclides for which the Procedure Is Performed

3. Are the sampling frequencies varied in reponse to:
a) differences in the effective half-life of the radionuclide
b) quantity of material worked with

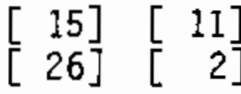

4. For which of the following are bioassay procedures
a) initiation of employment (a)
b) termination of employment
c) initiation of a project $(a)$
d) completion of a project (a)
e) routinely without regard for project schedules

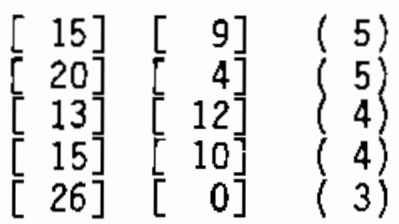

(a) One respondent indicated that bioassays are occasionally scheduled at these times, depending upon circumstances. 
5. Does your company conduct a diagnostic bioassay program?

[ 6] NO: Turn to Section IV.

[23] YES: Please indicate the procedures used to quantify an uptake of radioactive material, e.g., wholebody counting.

\section{Bioassay Procedure}

e.g. whole-body counting
Radionuclides for Which the Procedure Is Performed

6. In the table below, please indicate the number of samples analyzed at your facility in the last calendar year.

\begin{tabular}{l} 
Radioelement/ \\
Radionuclide Urine Samples. Fecal Samples Whole-Body/lung Counts \\
Plutonium \\
\hline Thorium \\
\hline Uranjum \\
\hline \\
\hline
\end{tabular}


SECTION IV. DATA ANALYSIS/INTERPRETATION

1. Please indicate the greatest extent to which data analyses/interpretations are performed at your facility.

Data Analyses:

LEFT

To what extent is data analys is performed?

a) No analysis performed (raw data recorded oniy) [ 5][16] $\underline{\text { YES }}$ NO BLANK

b) Estimate the activity in whole body at time of bioassay or measurement

c) Estimate the fraction of MPBB of the radionuclide

d) Estimate the activity in critical organ (only)

e) Estimate the activity in (several) specific organs

Interpretation:

What is the maximum extent of data interpretation?

a) Calculate dose-equivalent rate to critical organ at time of measurement

b) Calculate dose-equivalent rate to specifjc organs other than the critical organ at time of measurement

c) Calculate dose-equivalent rate to the whole body at time of measurement

d) Calculate quantity of intake (back calculate to estimate time of uptake)

Do you calculate a total dose for the calendar year to the:

a) Critical organ

b) Specific organs (if other than the critical organ)

c) Whole body

Do you calculate a 50-year dose commitment to the whole body?

2. If an uptake of radioactive material is indicated by bioassay data and the actual date of intake is unknown, when is the intake assumed to have occurred?

[9] a) day following last negative sample or count

[2] b) one day preceding the positive sample or count

[8] c) mid-time between the last negative sample or count date and the positive sample or count date

[17] d) other (piease state assumption) 
3. Mathematical mode] employed

a) Do you use mathematical models which describe the metabolism (uptake, distribution, and excretion) of radionuclides to assist in data analysis and dose interpretation?

[ 3] NO: Turn to Section V.

[ 24] YES: i. If the model has not been published in the open

literature, please attach a description of your model.

$j i$. If the model has been published in the open

literature, please give the reference(s)

iii. If the published model or the values of its parameters have been modified by your group, please explain the modifications.

\section{(2) LEFT BLANK}

b) Do you modify your method of dose interpretation for each individua? based on observations of actual metabolism?

[9] NO: Turn to Section $V$.

[ 16] YES: Please describe how the modifications are performed.

(4) LEFT BLANK 
SECTION V. QUALITY ASSURANCE

1. Does your bioassay program have a quality assurance program?

[ 26] YES: Please complete Tables V.1 and V.2.

[ 1] NO: Please turn to Section VI.

(2) LEFT BLANK

TABLE V.1. Minimum Detection Limits

In the table below please list the radionuclides for which you most commonly perform bioassays; also please list the minimum detection limit (MDL) for that radionuclide and the bioassay method for which the 1 imit applies.

Radionuclide

MDL

Method for which the MDL Applies 
TABLE. V.2. Quality Control Samples

In the following table, please indicate which types of quality control samples are used.

\begin{tabular}{l} 
QC Type - Please state frequency \\
of use of each type of quality control sample \\
\hline Radioassay Procedure \\
Urine analysis \\
\hline Blank Check Spiked Sample Open Audit Bind Audit \\
\hline Other (specify) \\
\hline Other (specify) \\
\hline Other (specify)
\end{tabular}

2. Does your bioassay program participate in bioassay
$\begin{aligned} & \text { intercomparison studies? } \\ & \text { yES }\end{aligned}$ 


\section{SECTION VI. AIR-MONITORING/SAMPLING PROGRAM}

1. Does your facility have an air-monitoring/sampling program?

[28] YES: If yes, please answer the remaining questions of this section. [ 0$]$ NO: If no, please turn to Section VII.

(1) LEFT BLANK

2. Does your air-monitoring/sampling program utilize

[ 0$]$ a) air monitors only

[3] b) air samplers only

[24] c) both air monitors and air samplers

[2] d) other (specify)

(0) LEFT BLANK

3. Where are the locations of the air monitors/samplers (please check all that apply)

[ 7] a) Lape1

[ 15] b) Hood face

[16] c) Glove box face

[17] d) Work area exhaust vent

[ 18] e) center of work area room

[ 14] f) other (please specify)

(1) LEFT BLANK

4. Does your facility depend solely on the air-monitoring/sampiing program for internal-dose estimates?

[ 0$] \frac{Y E S}{270}$

[ 27] NO

( 2) LEFT BLANK

5. Are the results of the air-monitoring/sampling program (whether air concentrations, MPC-hours, estimates of intake, or internal-dose estimates) routinely placed in personnel dosimetry files?

$\left[\begin{array}{c}4 \\ 23\end{array}\right] \frac{\mathrm{YES}}{\mathrm{NO}}$

( 2) TEET BLANK

6. If the results of air-monitoring/sampling program are placed in the personnel dosimetry files, how are the data recorded (e.g., $x$ hours at $\mu\left(j / m^{3}\right) ?$

7. If your facility has both an air-monitoring/sampling program and a bioassay program, have the estimates of radioactive-material intake/internal radiation dose of both programs been compared?

[ 5] YES: If yes, please describe how well the two estimates compare.

[ 22] NO: If no, please turn to Section VII.

(2) LEFT BLANK

(a) One respondent stated that air monitoring is used only for operational control. 
The purpose of this section is to obtain information relevant to recordkeeping systems. For purposes of this questionnaire, the exact location or filing system mechanism is not as important as is whether the records exist and whether the records are readily accessible.

\section{Personnel files}

Of the following items, which are included in the

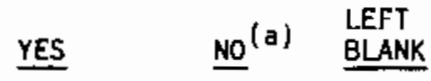
empioyee dosjgetry records or are readily available if required:
a) Nuclides of potential uptake
b) Schedule for routine bioassay
c) Respirator fit test data
d) Respirator protection factor
f) Radionuclide deposited
$[27]^{(f)} \quad[1]$
g) Body burden
h) Primary organ of deposition
$[22]^{(g)} \quad$ [5]
i) Organ burden
$[21]^{(f)}$
[ 6]
j) Estimated date of deposition of radionuclides
$\begin{array}{ll}{[20]^{(h)}} & {[8]} \\ {[22]^{(b, h)}} & {[6]} \\ {[14]^{(b, c, h)}} & {[14]}\end{array}$
k) Annual dose from internal deposition
1) Sum of external and internal doses (for year) (effective annual dose comitment)
m) Nuclide excretion data testing, monitoring/sampling, in-
urine or fecal analyses)
o) 50-year meighted dose commitment

[ 6] [22] ${ }^{(e)}$

(a) One respondent checked no to all but $c, f, m$, and $n$ because no significant intakes had occurred at the facility.

(b) At one facility, these are available on a limited basis for employees with highest exposure.

(c) Only if applicable, e.g. ${ }^{3} \mathrm{H}$.

(d) One respondent stated that the answers are often different for whole-body counts and radioassay data (the respondent did not elaborate).

(e) One respondent stated that 50-year dose comitments are calculated for principal organs of deposition.

(f) One respondent stated this is are recorded for in-vivo counts only.

(g) One respondent stated that this is recorded only when associated with identifiable incidents.

(h) One respondent stated that this is recorded only when required by DOE orders. 


\section{SECTION VIII. COMMENTS}

In this section please provide comments on internal-dosimetry programs, the difficulties involved, improvements which should be made, etc. The questions listed below are provided only to stimulate your thoughts.

1. What is the greatest source of error in the estimation of dose from internally deposited radionuclides?

2. What aspect of internal dosimetry (i.e., detection methods, metabolism models) is in need of the greatest improvement? If, in your opinion, there are several, please list them all in order of increasing importance.

3. For which radionuclides do you find quantification of uptake or body burden most difficult? Explain.

4. Does the current state of the art of internal-dosimetry measurements support calculation of weighted whole-body dose equivalents? If not, what would be required to allow the calculation of a weighted wholebody dose equivalent from internally deposited radionuclides?

5. If your internal-dosimetry program is not presently equipped to compute an annual weighted whole-body dose equivalent or a 50-year effective whole-body dose equivalent from internally deposited radionuclides, what enhancements would be required? 
APPENDIX B

MINIMUM DETECTION LIMITS FOR RADIONUCLIDES, TABULATED BY BIOASSAY TECHNIQUE 
MINIMUN UETEGTION LIMITS USING URINE ASSAY

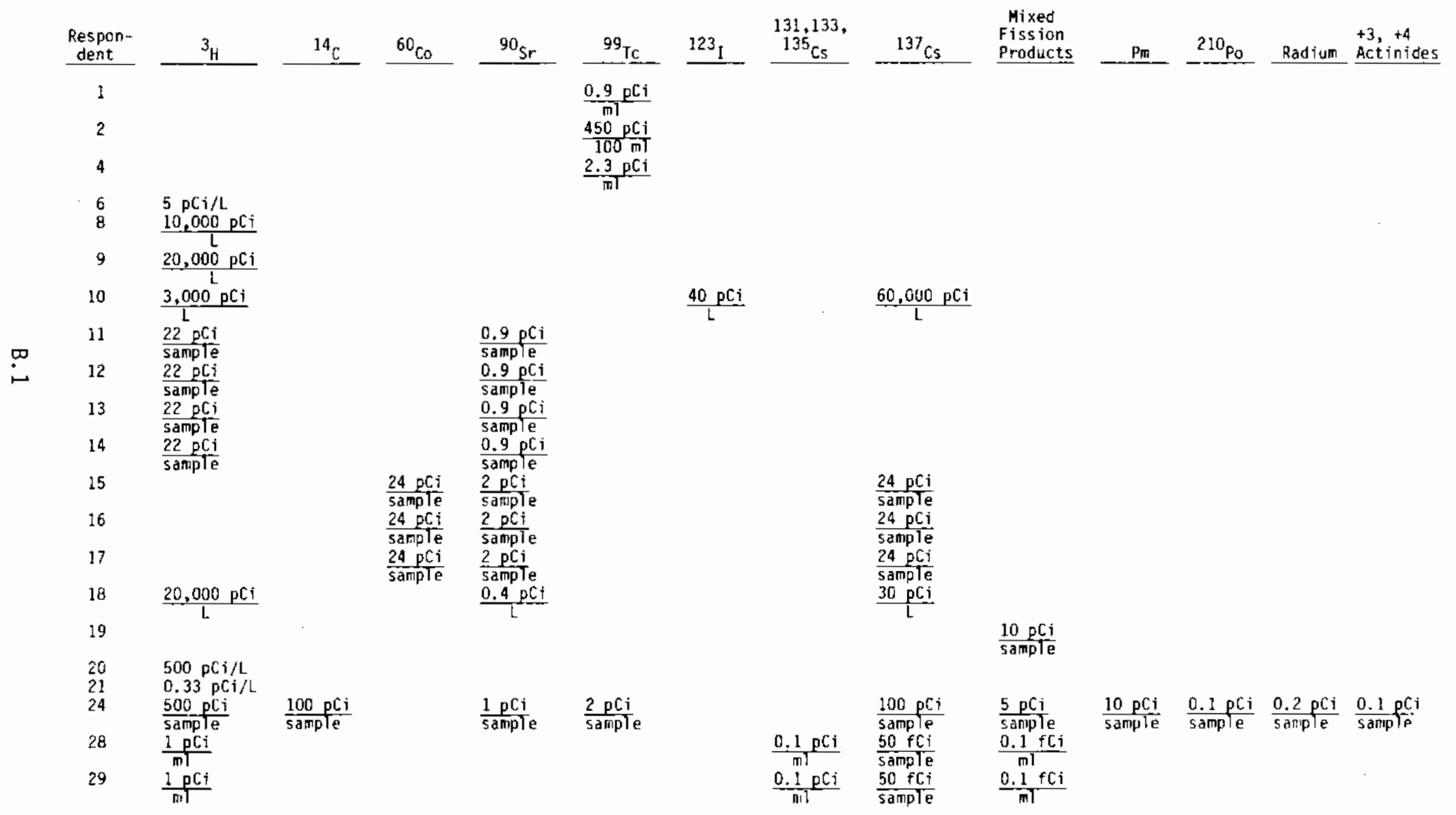


MINIMUM DETECTION LIMITS FOR URANIUM USING URINE ASSAY

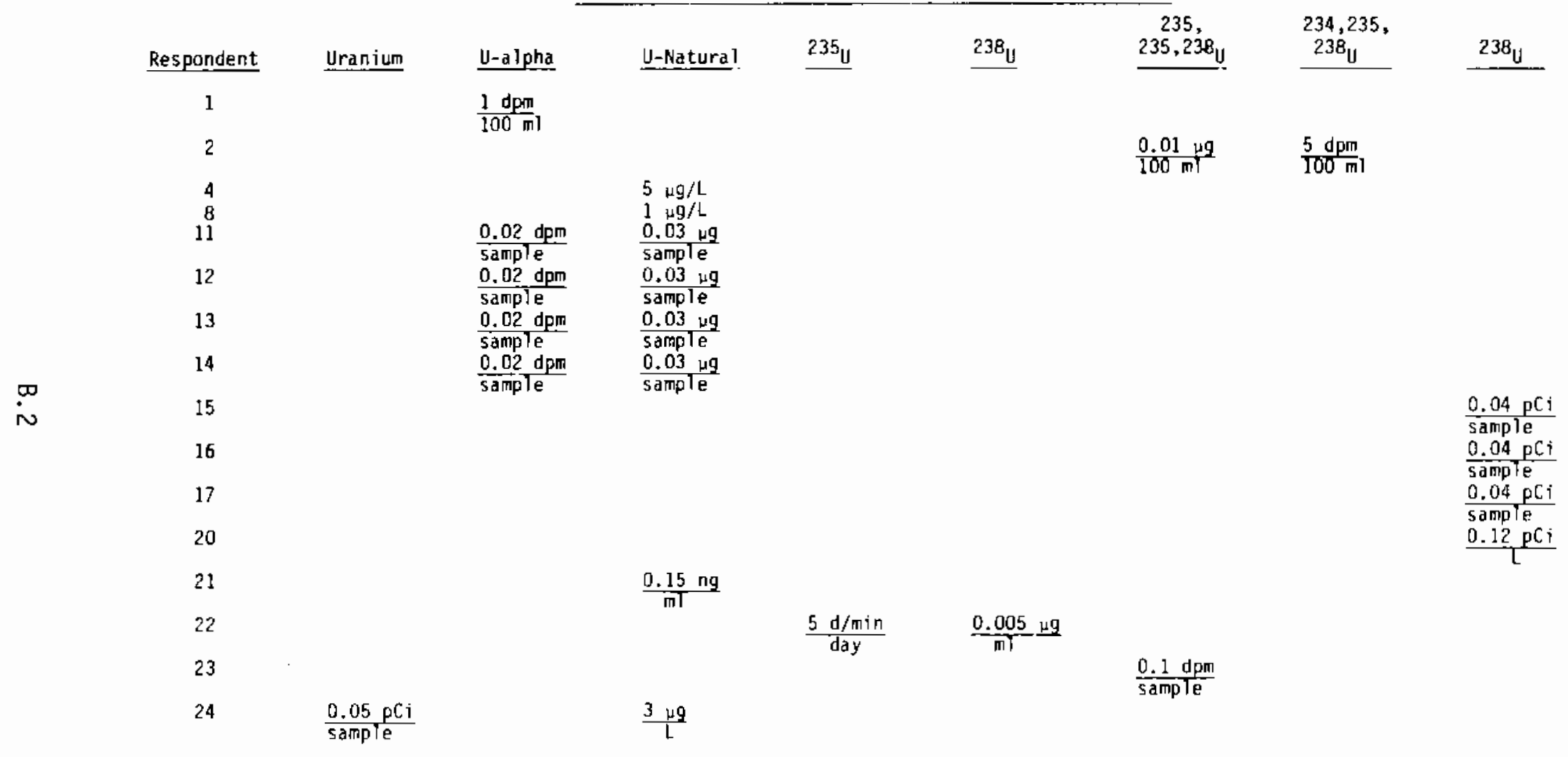


MINIMUM DETECTION LIMITS FOR PLUTONIUM USING URINE ASSAY

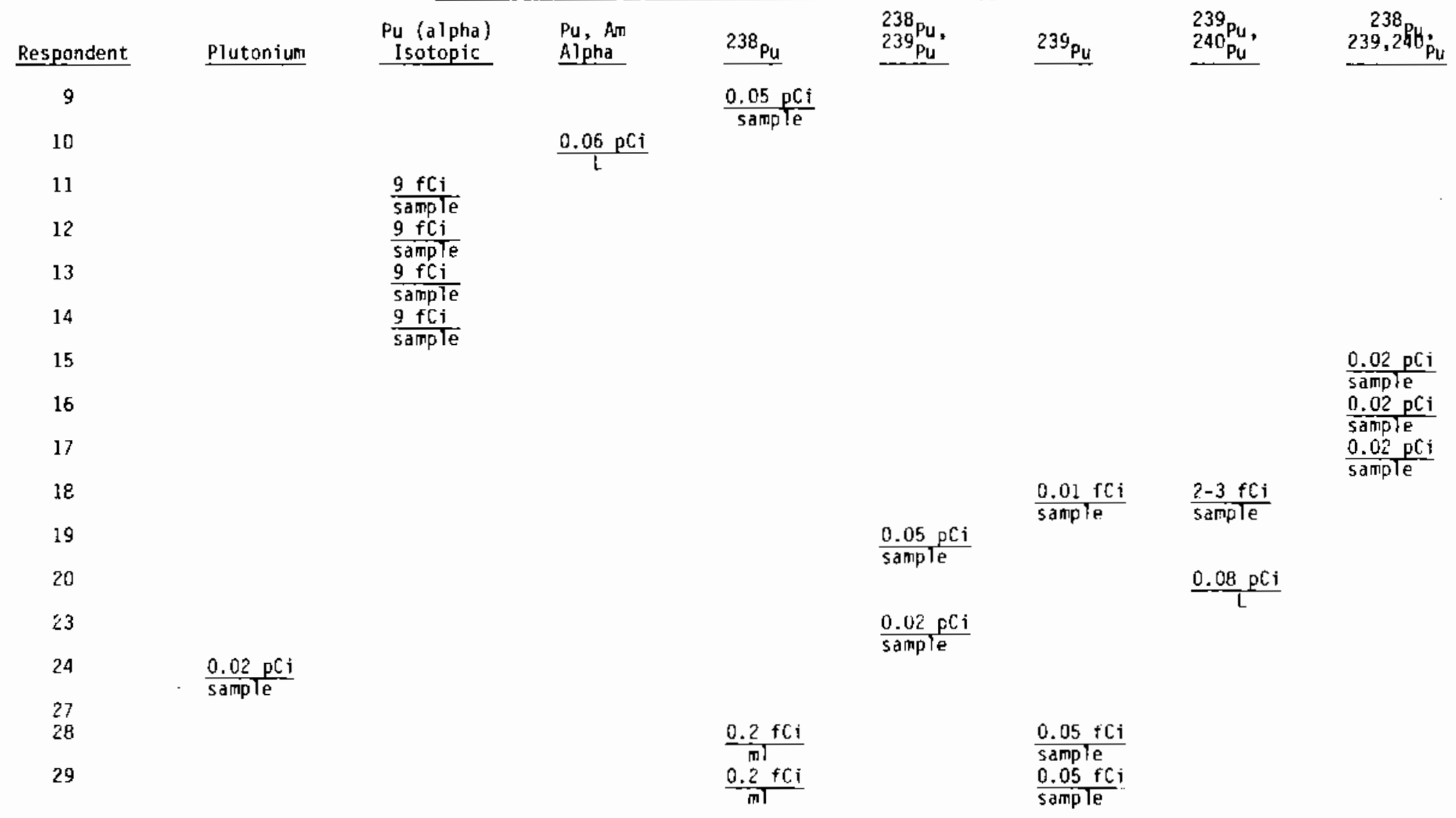


MINIMUM DETECTION LIMITS USING THYROIN COUNTS

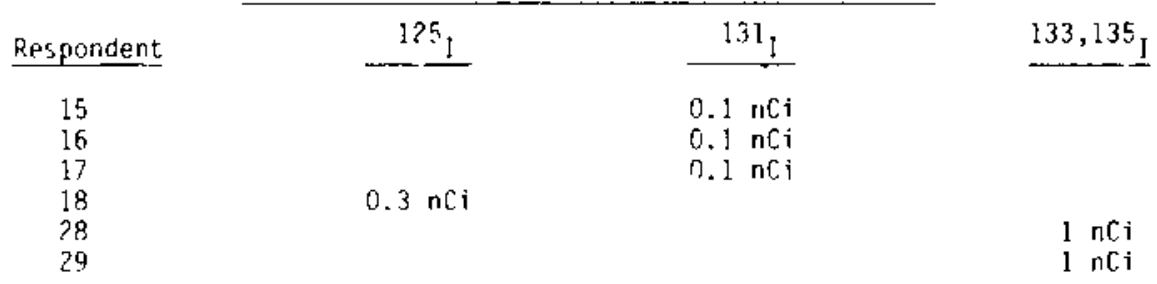

MINIMIJM OETECTION LIMITS USING SKIILL COLNTS

\begin{tabular}{cc} 
Respondent & ${ }^{90} \mathrm{Sr}$ \\
\cline { 3 - 3 } 15 & $30 \mathrm{nCi}$ \\
16 & $30 \mathrm{nCi}$ \\
17 & $30 \mathrm{nCi}$
\end{tabular}

MINIMUM DFIFCTION LIMITS USING IN-VIVO CHFST/LUNG COUNTING

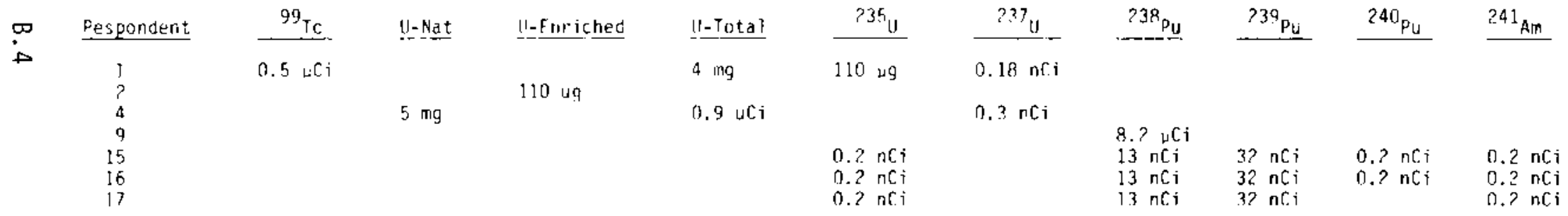

\begin{tabular}{|c|c|c|c|c|c|c|c|}
\hline \multirow[b]{2}{*}{ Respondent } & \multicolumn{6}{|c|}{ MINIMIIM DETFCTION LIMITS USING WHOLF-BODY COUNTING } & \multirow[b]{2}{*}{ Ganna $>100 \mathrm{keV}$} \\
\hline & ${ }^{60} \mathrm{Co}$ & ${ }^{99} T_{C}$ & ${ }^{137} \mathrm{cs}$ & ${ }^{20} \mathrm{Bi}$ & ${ }^{237} \mathrm{~Np}$ & Gamma-Emitter & \\
\hline $\begin{array}{r}? \\
10\end{array}$ & & 1 uCi & & & $0.2 \mathrm{nCi}$ & & $\operatorname{lncj^{(a)}}$ \\
\hline 15 & $3 \mathrm{nCi}$ & & $2 \mathrm{nCi}$ & & & & \\
\hline 16 & $3 \mathrm{nCj}$ & & $? \mathrm{nCi}$ & & & & \\
\hline 17 & $3 \cap \mathrm{Ci}$ & & $? \mathrm{nCi}$ & & & & \\
\hline 18 & $3 \mathrm{nCi}$ & & $3 \pi \mathrm{r} i$ & $3 \mathrm{nCi}$ & & & \\
\hline 24 & & & & & & $10 \mathrm{nCi}$ & \\
\hline
\end{tabular}

(a) Assumes 1 gamma/disintegration. 


\section{DISTRIBUTION}

No. of

Copies

OFFSITE

\section{Technical Information Center}

R. W. Barber, Acting Director

Nuclear Reactor and Facility Safety Division, PE-221

$\mathrm{U}$. S. Department of Energy

Washington, DC 20545

S. T. Brewer

Assistant Secretary for

Nuclear Energy, NE-1

U. S. Department of Energy

Washington, DC 20545

B. P. Brown, Leader

Process Facilities Safety, EP-341

U. S. Department of Energy

Washington, DC 20545

G. L. Chipman, Jr.

Deputy Assistant Secretary

Breeder Reactor Programs, NE-50

U. S. Department of Energy

Washington, DC 20545

F. E. Coffman, Director

Terminal Waste Disposal and

Remedial Action, NE-20

U. S. Oepartment of Energy

Washington, DC 20545

了. W. Culpepper, Deputy Asst. Sec.

Security Affairs, DP-30

U. 5. Department of Energy

Washington, DC 20545

L. J. Dea1, Acting Director

Division of Radiological Controls, PE-222

U. S. Department of Energy

Washington, DC 20545
No. of

Copies

L. A. Forsythe, Deputy Director Safety Environment and Emergency Actions, DP-226

U. S. Department of Energy

Washington, DC 20545

N. Goldenberg, Director

Safety $Q A$ and Safeguards, NE-74

U. S. Department of Energy

Washington, DC 20545

Major General W. W. Hoover, USAF

Deputy Assistant Secretary for

Military Application, DP-20

U. S. Department of Energy

Washington, DC 20545

B. R. House, Deputy Asst. Sec.

Energy Emergencies, EP-40

U. S. Department of Energy

Washington, DC 20545

A. G. Joseph, Director

Office of Field Operations

Management, ER-40

U. S. Department of Energy

Washington, DC 20545

K. 0. Laughon, Sr., Director

Dffice of Spent Fuel Management and

Reprocessing Systems, NE-40

U. S. Department of Energy

Washington, DC 20545

J. R. Maher, Director

Nuclear Safety Office, PE-22

U. S. Department of Energy

Washington, DC 20545

J. W. Mares, Asst. Secretary

Policy, Safety, \& Environment, EP-1

U. S. Department of Energy

Washington, OC 2 D545 
No. of

Copies

S. Matovich, Director

Safety \& Quality Assurance Staff

Nuclear Materials Prod, DP-13

U. S. Department of Energy

Washington, DC 20545

Admiral K. R. Mckee

Deputy Assistant Secretary for Nava 1 Reactors, NE-6D

U. S. Department of Energy

Washington, DC 20545

W. E. Mott, Technical Assistant

Office of Operational Safety, EP-323

U. S. Department of Energy

Washington, DC 20545

M. P. Norin

Office of Support \& Programs, NE-74

U. S. Department of Energy

Washington, DC 20545

D. E. Patterson, Director Office of Operational Safety, $\mathrm{PE}-24$

U. S. Department of Energy

Washington, DC 20545

B. Siebert, Director

Policy, Planning, and Coordination Staff, DP-31

U. S. Department of Energy

Washington, DC 20545

R. J. Stern, Director

Environmental Compliance, EP-36

U. S. Department of Energy

Washington, DC 20545

L. E. Temple, Director

Construction Management, ER-65

U. S. Department of Energy

Washington, OC 20545
No. of

Copies

J. W. Thiessen, Deputy Assoc. Dir. Office of Health \& Environmental

Research, ER-71

U. S. Department of Energy

Washington, OC 20545

R. E. Titler, Acting Deputy

Assistant Secretary

Environment, Safety, and Health, PE-20

U.S. Department of Energy

Washington, DC 20545

A. W. Trivelpiece, Director

Office of Energy Research, ER-1

U. S. Department of Energy

Washington, DC 20545

E. U. Valtario, Manager

Health Physics

Radiological Controls Div., EP-342

U. S. Department of Energy

Washington, DC 20545

W. D. Burnett, Manager

Health Physics Division

DOE Sandia National Laboratories

Mail Code 3312, Bldg. 8619

P. 0. Box 2800

Albuquerque, MM 87115

J. E. Dummer, Group Leader

Health Physics

Los A7 amos National Laboratory

P. 0. Box 1663

Los Alamos, NM 87545

E. P. Forest, Manager

Environmental Health \& Safety

Neutron Devices Department

General Electric Company

P. 0. Box 11508

St. Petersburg, FL 33733 
No. of

Copies

H. E. Meyer, Manager

Health Physics

Mound Laboratory

Monsanto Research Corporation

P. 0 . Box 32

Miamisburgn, $\mathrm{OH} 45342$

H. Phillips, Safety Director

Pantex Plant

Mason \& Hanger--Silas Mason Co., Inc.

P. 0. Box 30020

Amarillo, TX 79177

P. M. Ramey

Albuquerque Operations office

U. S. Department of Energy

P. 0. Box 5400

Albuquerque, NM 87115

1. J. Thompson

Lovelace Biomedical \& Environmental

Fiesearch Laboratories

Health Protection Operations

P. 0. Box 5890

Alburquerque, NM 87115

R. E. Yoder, Director

Health, Safety, and Environment

Rockwell International

P. 0. Box 888

Go den, CO 80401

L. V. CouTson, Head

Safety Section

Fermi National Accelerator Laboratory

P. 0 , Box 500

Batavia, IL 60510

C. B. Meinhold, Head

Safety \& Environmental Protection Division

Brookhaven National Laboratory

Associated Universities, Inc.

Upton, NY 11973
No. of

Copies

R. Moser, Director

Operational \& Environmental Safety Division

Chicago Operations office

U. S. Department of Energy

9800 South Cass Avenue

Argonne, IL 60439

D. A. Waite

Battelle Columbus Laboratories

505 King Street

Columbus, $\mathrm{OH} 43201$

J. H. Barry, Oirector

Operational Safety Division

Idaho Operations Office

U. S. Department of Energy

550 2nd Street

Idaho Falls, I0 83401

B. 3. Beers, Assistant Manager

Environmental, Safety and Health Programs

Idaho Operations office

U. S. Department of Energy

550 2nd Street

Idaho Falls, ID 83401

B. L. Rich

Health and Safety Division

EG\&G Idaho

P.0. Box 1625

Idaho Falls, ID 83401

A. C. Davis, Manager

Rettis Atomic Power Lab. (DOE)

Westinghouse Electric Corporation

P. $0.80 \times 79$

West Mifflin, PA 15122

T. L. Collins, Manager

Knol is Atomic Power Laboratory

II. S. Department of Energy

P. 0. Box 107 ?

Schenectady, NY 12301 
No. of

Copies

C. K. Gaddis, Manager

Pittsburgh Naval Reactors Office

P. 0. Box 109

W. Mifflin, PA 15122

A. E. Bicker

Reynolds Electrical \& Engineering Co., Inc.

P. 0. Box 14400

Las Vega, NV 89114

B. W. Church

Health Physics Division

Nevada Operations Dffice

U. S. Department of Energy

P. 0. Box 14100

Las Vegas, NV 89114

S. R. Elliot, Director

Office of Safety and Health

Nevada Operations Office

U. S. Department of Energy

P. 0. Box 14100

Las Vegas, NV 89114

M. W. Boback, Director

Health and Safety

National Lead Company of Ohio

P. 0. Box 39158

Cincinnati, OH 45239

W. R. Golliher, Manager

Health, Safety and Environmental Affairs

0ak Ridge Gaseous Diffusion Plant

P. 0. Box $P$

Oak Ridge, TN 37831

C. M. Hutchings, Administrator

Medical, Safety, and Environment

Goodyear Atomic Corporation

P. 0. Box 628

Piketon, $\mathrm{OH} 45661$
No. of

Copies

J. B. McLendon, Director

Radiation Safety, $\mathrm{Y}-12$

Nuclear Division

Union Carbide Corporation

P. 0. Box Y

Oak Ridge, TN 37830

DC Parzyck, Director

Environmental and 0ccupational

Safety Division

Oak Ridge National Laboratory

P. 0. Box $X$

0ak Ridge, TN 37830

W. E. Thompson

Health, Safety, and Environmental Control

Paducah Gaseous Diffusion Plant

P.0. Box 1410

Paducah, KY 42001

W. H. Travis, Director

Safety \& Environmental Control

Division

0ak Ridge Operations Office

U. S. Department of Energy

P. 0. Box E

Oak Ridge, TN 37830

J. C. White, Manager

Technical Services

Nuclear Division

Union Carbide Corporation

0ak Ridge, TN 37830

J. T. Davis, Chief

Operational Safety and Compliance San Francisco Operations Office

U. S. Department of Energy

1333 Broadway

Dakland, CA 94612 
No. of

Copies

W. E. Keheley, Branch Chief Environment and Nuclear Safety

San Francisco Operations Office

U. S. Department of Energy

1333 Broadway (Wells Fargo B1dg)

Oakland, CA 94612

R. C. McCal1, Rad. Safety Officer

Stanford Linear Accelerator

P. 0. Box 4349

Stanford, CA 94305

R. H. Thomas

DOE Lawrence Berkeley Nationa? Laboratory

University of California

Berkeley, CA 94720

A. J. Toy, Head

Hazardous Control Department

Lawrence Livermore National Lab.

P. 0. Box 808

Livermore, CA 94550

W. A. Reese, Director

Safety and Environmental Division

Savannah River Operations Office

$U$. S. Department of Energy

P. 0. Box A

Aiken, SC 29801

W. C. Reining, Superintendent

Health Protection Department

E.I. DuPont De Nemours and Company

Savannah River Plant

Aiken, SC 29809
No. of

Copies

A. Richardson

Criteria \& Standards Division, AW-460

401 M Street, SW

Washington, DC 20460

U. C. Villforth, Director

FDA Bureau of Radiological Health

Rockville, MD 20852

R. E. Alexander, Chief

Occupational Radiation Branch

Office of Nuclear Regulatory

Research

Nuciear Regulatory Commission

Washington, DC 20555

P. E. Minogue, Director

Office of Nuclear Regulatory

Research

Nuclear Regulatory Commission

Washington, DC 20555

D. Mutler, Assistant Director

Environmental Technology

Office of Nuclear Reactor

Regulation

Nuclear Regulatory Commission

Washington, DC 20555

L. C. Rouse, Chief

Advanced Fuel and Spent Fuel

Licensing Branch

Division of Fuel Cycle \& Material Safety

Nuclear Regulatory Commission

Washington, DC 20555

M. J. Sires III, Assistant Manager ONSITE

Health Safety and Environment

Savannah River Operations Office

4 DOE Richland Operations Office

U. S. Department of Energy

P. 0. Box A

Aiken, SC 29801

P. K. Clark/H. E. Ransom

D. R. Elle

R. E. Gerton

G. R. Yesberger 
No. of

Copies

3 Rockwell - Hanford
W. A. Decker
B. E. Knight
B. J. Saueressig

1 Hanford Environmental Health Foundation

R. D. Gilmore

3 UNC Nuclear Industries

D. F. Brendel

W. L. Ness

D. J. Pisarcik

4 Westinghouse Hanford Co.

R. 0. Budd

G. D. Carpenter

W. P. Howell

R. L. Watts
No. of

Copies

46 Pacific Northwest Laboratory

ป. B. Berry

P. E. Bramson

E. H. Carbaugh

L. C. Carrick

R. L. Dirkes

J. T. Denovan

T. H. Essig

L. G. Faust

D. R. Fisher

W. M. FTeming

W. A. Glass

K. R. Heid

D. P. Higby

G. R. Hoenes

J. L. Kenoyer

H. V. Larson

A. P. Mileham

B. L. Murphy (6)

N. P. Nisick

K. R. Price

A. V. Robinson

J. M. Selby

K. L. Swinth

R. J. Traub (10)

Radiological Sciences Library

Publishing Coordination (2)

Technical Information (5) 